NASA Technical Memorandum 106610

AIAA-94-3011

\title{
Operating Characteristics of the Russian D-55 Thruster with Anode Layer
}

John M. Sankovic and Thomas W. Haag National Aeronautics and Space Administration

Lewis Research Center

Cleveland, Ohio

and

David H. Manzella

NYMA, Inc.

Engineering Services Division

Brook Park, Ohio

Prepared for the 30th Joint Propulsion Conference cosponsored by AIAA, ASME, SAE, and ASEE Indianapolis, Indiana, June 27-29, 1994

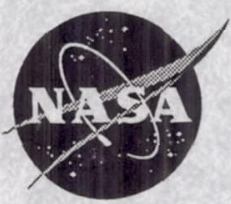

National Aeronautics and Space Administration 


\title{
OPERATING CHARACTERISTICS OF THE RUSSIAN D-55 THRUSTER WITH ANODE LAYER
}

\author{
John M. Sankovic* and Thomas W. Haag** \\ National Aeronautics and Space Administration \\ Lewis Research Center \\ Cleveland, Ohio \\ and \\ David H. Manzella ${ }^{\dagger}$ \\ NYMA, Inc. \\ Engineering Services Division \\ Brook Park, Ohio
}

\begin{abstract}
Performance measurements of a Russian engineering-model Thruster with Anode Layer (TAL) were obtained as part of a program to evaluate the operating characteristics of Russian Hallthruster technology. The TAL model D-55 was designed to operate in the 1-2 $\mathrm{kW}$ power range on xenon. When received, the thruster had undergone only a few hours of acceptance testing by the manufacturer. Direct thrust measurements were obtained at a background pressure of 0.0003 $\mathrm{Pa}\left(2 \times 10^{-6}\right.$ torr $)$ at power levels ranging from $0.3 \mathrm{~kW}$ to $2.1 \mathrm{~kW}$. At the nominal power level of $1.3 \mathrm{~kW}$, a specific impulse level of $1600 \mathrm{~s}$ with a corresponding efficiency of 0.48 was attained. At all flow rates tested, the efficiency increased linearly with specific impulse until a maximum was reached, and then the efficiency leveled off. Increasing the anode flow rate shifted the efficiency upward, reaching 0.50 at 1850 s specific impulse. The thruster was equipped with inner and outer electromagnets which were isolated from the discharge and from each other. Variation of the magnetic field, obtained by changing the currents through the magnets, had little effect on performance, except at current levels below $70 \%$ of nominal. For a given operating condition, the performance was slightly affected by facility pressure. As the pressure was increased by a factor of thirty to $0.008 \mathrm{~Pa}\left(6 \times 10^{-5}\right.$ torr $)$, the current steadily increased by $4 \%$, and the thrust increased by $2 \%$. Performance comparisons were made with the Stationary Plasma Thruster, and the efficiency and specific impulse values were similar at power levels ranging from $0.9 \mathrm{~kW}$ to $1.5 \mathrm{~kW}$. Endurance testing was not performed, and comparisons of lifetime were not made.
\end{abstract}

\section{INTRODUCTION}

During the past several years the Innovative Science and Technology Directorate of the Ballistic Missile Defense Organization (BMDO) has been evaluating Russian electric propulsion technologies which have the potential to greatly enhance the performance of Western spacecraft. Of particular interest to the BMDO are the Russian "Hall" thruster technologies, including the Stationary Plasma Thruster (SPT) and the Thruster with Anode Layer (TAL).

In 1991 the BMDO sponsored a trip to Russia to evaluate the Stationary Plasma Thruster (SPT). The success of that trip led to the acquisition of an SPT-100 thruster and evaluation of the device in US Government electric propulsion testbeds at NASA Lewis Research Center (LeRC) and

\footnotetext{
*Aerospace Engineer, On-Board Propulsion Branch, Member AIAA

**Aerospace Engineer, On-Board Propulsion Branch

${ }^{\dagger}$ Research Engineer

Copyright (C) 1994 by the American Institute of Aeronautics and Astronautics, Inc. No copyright is asserted in the United States under Title 17, U.S. Code. The U.S. Government has royalty-free license to exercise all rights under the copyright claimed herein for Government purposes. All other rights are reserved by the copyright owner.
} 
the Jet Propulsion Laboratory (JPL). 1 At NASA LeRC, performance measurements have been obtained and a breadboard power processing unit (PPU) has been integrated with the SPT-100.2,3 Spacecraft contamination issues were addressed through direct measurement of erosion/deposition on samples placed in the plume. 4 Optical diagnostic techniques were employed to define the plume signature, and a laser induced fluoresence technique was used to determine azimuthal ion velocities in order to quantify induced torques on the spacecraft. 5,6 Measurements of the plasma plume electron number density and temperature have been obtained under a program to provide data for communications signal impact models. ${ }^{7}$ Radiated electromagnetic interference (EMI) from the SPT-100 operating on a Government breadboard PPU has also been measured over the frequency range of 14 $\mathrm{kHz}-40 \mathrm{GHz} .8$ International Space Technology, Inc. (ISTI) which is a consortium of Fakel Enterprise (Russia), the Research Institute of Applied Mechanics and Electrodynamics of Moscow Aviation Institute (Russia), Space Systems Division of Loral Corp. (USA), Atlantic Research (USA), and SEP (France), are marketing the SPT-100 system for Western spacecraft. 9 Under a NASA Space Act Agreement with Space Systems/Loral, evaluations of integration issues are continuing at LeRC. At JPL, the BMDO and Space Systems/Loral (SS/L) are sponsoring a lifetest of the SPT-100 system. This test is being performed using an SS/L breadboard PPU integrated with a flightrepresentative thruster and should provide valuable information on insulator erosion and temporal variation of performance. 10

While the SPT has an extensive flight history, the TAL is currently a laboratory device. A summary of the TAL state-ofthe-art is provided by Lyapin, et al.11 In 1992, the BMDO sponsored a trip of US specialists to the Central Scientific Research Institute of Machine Building (TsNIIMASH) in Russia to investigate the TAL technology. After that trip several TAL's were obtained and are currently under investigation to determine if the TAL offered any advantages over the SPT, such as improved performance, longer life, or decreased plume divergence.

The SPT and TAL are very similar, the main physical difference being the discharge chamber walls which are dielectric in the SPT and metallic in the TAL. An overview of the two Russian technologies which discusses the difference in physics due to the discharge chamber wall material is provided in Ref. 12 .

The TAL evaluation program being conducted at NASA LeRC is focused on performance, plume property, and component life evaluations. The program is also identifying system improvements which could be achieved via the insertion of Western technology, such as the NASA LeRC hollow cathode technology developed under the Space Station Plasma Contactor Program 13 and advanced power electronics in the PPU. 3 This paper discusses the results obtained at NASA LeRC in the first step of this process of thruster evaluation. Direct thrust measurements were obtained to determine the performance of the TAL at various operating conditions. Parameters varied include discharge voltage and current, propellant flow through both the anode and cathode, and the magnetic field. The effects of the test facility on thruster operation were also documented by varying the facility pressure. Finally, comparisons are made between the performance of the SPT -100 and the TAL model D-55.

\section{EXPERIMENTAL APPARATUS}

\section{THRUSTER}

All testing was performed on a single Thruster with Anode Layer, model number D-55. The thruster was procured by Texas Tech University under a BMDO sponsored grant. A photograph of the thruster is provided as Figure 1a and a schematic is included as Figure 1b. The model designation refers to the diameter at the center of the discharge chamber in 
millimeters. The thruster is equipped with two independent magnetic circuits. Three solenoids in series positioned evenly around the discharge comprise the outer magnet, while the inner magnet is a single solenoid. For the TAL the discharge chamber walls are metallic and the anode is a deep, annular channel, unlike the SPT. Propellant is injected through a series of holes at the back of the anode to insure even distribution. The thruster was supplied with a single hollow cathode which was equipped with a keeper electrode and was designed for heaterless ignition. The keeper is an electrode in close proximity to the cathode which is used to facilitate ignition. In some cases during steady-state operation, current is drawn to the keeper, in addition to the main discharge current, in order to maintain an elevated cathode temperature and aid electron emission.

\section{POWER PROCESSOR}

All steady-state testing reported herein was performed using commercially available SCR-controlled power supplies. The ignition circuitry was developed inhouse. An electrical schematic of the test set-up necessary to operate the thruster is provided in Figure 2. The discharge supply was run in constant voltage mode with a set current limit, typically 6 A. A $10 \Omega$ ballast resistance in series with the anode was used to limit the current from the internal capacitance of the discharge supply upon start-up. A $100 \mu \mathrm{F}$ capacitor was placed across the discharge to prevent plasma oscillations from affecting the discharge power supply. A $2000 \mathrm{~V} / 0.25$ A dc supply was used to achieve initial breakdown between the cathode and the keeper electrode. A dc supply operated in current control mode was then used to maintain a discharge beween the cathode and keeper electrode. All three supplies used the cathode potential as a common, and the cathode potential was allowed to float relative to ground. Two separate supplies were necessary to operate the magnets which were electrically isolated from the thruster and each other.

\section{FACILITY}

Performance testing of the thruster was conducted in a large space propulsion testbed which is descibed in detail in Ref. 14. A schematic of the chamber is provided in Figure 3. Briefly, the vacuum chamber is $5 \mathrm{~m}$ in diameter and $20 \mathrm{~m}$ in length. It is equipped with a helium cryopump system with an effective area of $41 \mathrm{~m}^{2} \cdot 14,15$ The helium cryopump was cooled to $20 \mathrm{~K}$ using gaseous helium and was shrouded by a liquid nitrogen panel. The facility is also equipped with twenty $0.8 \mathrm{~m}$ diameter oil-diffusion pumps operating on silicon oil. The total combined pumping speed on xenon exceeded $320,000 \mathrm{l} / \mathrm{s}$. The thruster was mounted on a thrust stand inside the main volume of the facility and positioned on centerline to achieve the lowest possible operating pressures.

The thrust stand was of an inverted pendulum design described in Ref. 16 and was used for previous SPT-100 performance tests. ${ }^{2}$ The thrust stand was calibrated insit $u$ by loading with three $39.2 \mathrm{mN}$ weights. It was mounted in the vacuum chamber as shown in Figure 4. The thrust stand was equipped with an inclinometer, a leveling motor, and a locking mechanism. The uncertainty of the thrust measurements, determined by examination of the hysteresis and zero drift, was within $\pm 0.5 \mathrm{mN}$.

The TAL was not equipped with a flow system, and the propellant flows to the cathode and anode were controlled manually outside of the vacuum facility. The anode and cathode propellant flow rates were regulated by $100 \mathrm{sccm}$ full-scale and $20 \mathrm{sccm}$ full-scale thermal-conductivity flow controllers, respectively. The controllers were calibrated in-situ using a constant volume technique. The uncertainty of the anode flow was determined to be with $\pm 1 \%$ of the reading. The uncertainty of the cathode flow was $\pm 10 \%$, due to temporal drifts. Hermetic integrity was checked by using a helium leak detection system. This was not possible at the final 
fittings connecting the thruster to the propellant system. Those fittings were bubble checked by flowing nitrogen through the anode and cathode. The purity of the xenon used was 0.99999 .

\section{INSTRUMENTATION}

Electrical measurements were taken using isolated digital multimeters (DMM) with a nominal input impedance of 10 Megohms. Discharge current was measured using the shunt contained in the DMM. The magnet currents were measured using Hall-current sensors. Additional Hall-current sensors with a frequency range of $\mathrm{DC}$ to $15 \mathrm{MHz}$ were used to monitor the discharge power supply current, keeper current, and current through the filter capacitor. The Hallcurrent sensors were connected to a digital oscilloscope with a $1 \mathrm{GHz}$ frequency response. The oscilloscope was also used to monitor the discharge voltage differentially. Similar meters were used for SPT-100 performance testing and agreed to within $0.05 \mathrm{~A}$ of the calculated RMS value of the signal during all operating modes. 2 The ground to cathode potential was also measured using a DMM connected at the power feedthrough on the vacuum facility.

Facility pressures reported herein were measured using an ionization gauge fixed on the thrust stand mounting structure. The gauge is shown in Figure 4 and was positioned $0.2 \mathrm{~m}$ from the thruster centerline and $0.7 \mathrm{~m}$ behind it. A ground screen was used at the inlet to the gauge to prevent interactions with the plasma. The gauges were calibrated using air as a reference, and all values reported were corrected for xenon, assuming the base pressure was air. Corrections were accomplished by subtracting the operating pressure from the base pressure, dividing by a gas sensitivity factor of 3.217 , and then adding the base presssure.

\section{EXPERIMENTAL PROCEDURE}

All testing was performed with representatives from TsNIIMASH present.
Because of the metallic discharge chamber, the TAL did not have the requirement of extended exposure at high-vacuum levels for outgassing and could be operated within a few hours of pumpdown. 2 The thruster was mounted on the thrust stand on centerline of the test facilty $3.6 \mathrm{~m}$ from the mid-tank shield shown in Figure 3. To achieve the highest possible pumping speed both the helium cyrosystem and all twenty of the diffusion pumps were used, and the mid-tank shield was removed during the TAL testing. The effect of facility pressure on thruster performance was evaluated by first turning off the diffusion pumps during thruster operation and allowing the facility pressure to increase without externally injecting gas. However, because the pumping speed of the cryosystem was not throttleable, a maximum pressure of $0.0004 \mathrm{~Pa}\left(3 \times 10^{-6}\right.$ torr) was achieved in this manner. The injection of xenon into the facility, independent of the thruster, allowed facility pressures of up to $0.008 \mathrm{~Pa}\left(6 \times 10^{-5}\right.$ torr) to be achieved.

The thrust stand was calibrated in-situ by loading the apparatus with calibrated weights, before, during, and after test runs. Thermal distortions were corrected by the use of the leveling motor and inclinometer. Current was passed through both sets of thruster coils, and magnetic tares were found to be negligible. As a final test to insure accurate thrust measurements, the thrust stand was mechanically locked periodically during testing to check for plasma effects on the electronics.

Initial xenon flow rates through the anode and the cathode were $3 \mathrm{mg} / \mathrm{s}$ and $2 \mathrm{mg} / \mathrm{s}$, respectively. The magnet supplies were adjusted to provide $3 \mathrm{~A}$ to the inner coil and $1 \mathrm{~A}$ to the outer coils. The ignitor power supply was used to provide the initial breakdown between the keeper and the cathode. The cathode provided with the thruster was heaterless and required up to 2 $\mathrm{kV}$ for breakdown. Once the discharge was initiated the keeper power supply was brought on-line, the current was increased to $2 \mathrm{~A}$, and the ignitor supply was turned 
off. The voltage on the discharge supply was then slowly increased from zero to the nominal operating point of $300 \mathrm{~V}$ with ignition of the main discharge, typically occuring at 50-100 V. A current limit of $6 \mathrm{~A}$ was set on the discharge supply to prevent damage to the thruster during start-up. Once the main discharge was on, the cathode flow rate was reduced to $1 \mathrm{mg} / \mathrm{s}$. The thruster was allowed to operate at this condition for at least thirty minutes to allow the structure to outgas. After that time, the test plan was initiated, and data were recorded.

\section{RESULTS AND DISCUSSION}

\section{VARIATION OF DISCHARGE VOLTAGE AND CURRENT}

In Russian TAL literature, efficiency and specific impulse are often calculated excluding the cathode flow. All the performance parameters presented in the tables were calculated using the total propellant flow. In some cases, it is quite useful to normalize the performance data via exclusion of the cathode flow in calculations. Throughout this paper, all performance parameters calculated by excluding the cathode flow are represented as closed symbols, while those which account for the total propellant flow are represented by open symbols.

The performance of the thruster at various power levels is provided in Table I. The test matrix chosen reflected previous operating experience with the same thruster in Russia, and the magnetic field strengths selected for the various flow conditions were recommended by the manufacturer, TsNIIMASH.

The TAL is similiar to the SPT in that the voltage is held constant, while the current is controlled by throttling the propellant flow rate. In general, the thruster was operated with a nominal keeper current of 2 A resulting in a corresponding power loss of approximately $25 \mathrm{~W}$. At selected points, the thruster was operated with the keeper off, and the performance was unaffected; therefore, it was assumed that a cathode design which eliminates the need for a keeper during steady-state operation could be developed, and the keeper power was excluded in the efficiency values. Magnet power losses were included in all efficiency calculations. At a power level of $1350 \mathrm{~W}$ the SPT-100 magnet dissipates approximately $20 \mathrm{~W}$ of power. In comparison, the D-55 TAL magnets were found to dissipate approximately $45 \mathrm{~W}$ in the steady-state condition.

Current-voltage characteristics at various anode flow rates are provided in Figure 5 for a constant cathode flow rate of 0.99 $\mathrm{mg} / \mathrm{s}$. The anode flow rates of 2.65, 3.57, 4.52 , and $5.50 \mathrm{mg} / \mathrm{s}$ were chosen to provide a discharge current range from $2 \mathrm{~A}$ to $6 \mathrm{~A}$. The nominal operating condition was $4 \mathrm{~A}$ which required an anode flow rate of 4.52 $\mathrm{mg} / \mathrm{s}$. The data show that current increased exponentially with voltages below the nominal level of $300 \mathrm{~V}$. The abrupt current increase limited operation to $150 \mathrm{~V}$ or above, except for the lowest flow rates. At voltages over $300 \mathrm{~V}$, the current was essentially constant.

The current/voltage characteristics were found to be steady throughout the testing. Figure 6 shows typical oscilloscope traces at an operating point of $4.5 \mathrm{~A}, 300 \mathrm{~V}$. The discharge voltage oscillations were typically less than $1 \mathrm{Vp}-\mathrm{p}$, and the current from the power supply was similarly quiet with less than a $0.1 \mathrm{Ap}-\mathrm{p}$ oscillation. The current from the capacitor across the discharge had oscillations up to 1 Ap-p. The RMS discharge current is equivalent to the RMS current from the discharge power supply, since the RMS of the capacitor current must equal zero. The instantaneous current through the thruster discharge is the sum of the current through the capacitor and the current from the power supply.

A plot of thrust as a function of power at four different anode propellant flow rates is provided as Figure 7. The graph shows that at a given power level, the thrust increases with flow rate. Since the current is proportional to flow rate, at a fixed power level, greater thrust can be achieved 
by increasing the current at the expense of acceleration voltage.

The specific impulse and the efficiency as functions of power are shown in Figure 8. At a given power level, the highest specific impulse occurs at the lowest mass flow rate, and higher specific impulse can be attained by increasing the voltage and decreasing the current. Figure $8 \mathrm{~b}$ shows that, in general, at a given flow rate the efficiency increases steeply with power until a maximum is reached, any further increases in power, which are achieved through voltage increases, have little effect on the efficiency. Increasing the propellant flow rate increased the maximum efficiency with the effect appearing to asymptote at the highest anode flow rate of $5.50 \mathrm{mg} / \mathrm{s}$. The cathode mass flow rate was excluded for the performance parameters plotted in Figure 8 , in order to normalize the data.

Efficiency as a function of specific impulse is plotted in Figure 9. The effect of excluding the cathode flow rate on the performance parameters can be determined by comparing Figures $9 \mathrm{a}$ and $9 \mathrm{~b}$. At the lowest anode flow rate, the difference between the two figures is greatest, since the cathode flow fraction of 0.27 is the greatest. The effect diminishes as the anode flow rate increases, causing the cathode flow fraction to correspondingly decrease. The effect is still significant at the highest flow rate of $5.50 \mathrm{mg} / \mathrm{s}$ because the cathode flow fraction is still relatively high at 0.15 . In both figures similar trends are noted. The efficiency increases linearly with specific impulse and then levels off. Increases in anode flow rate shift the curves upward, and the effect begins to asymptote at the highest anode flow rate tested.

\section{EFFECTS OF MAGNETIC FIELD STRENGTH}

The effects on thruster operation obtained by varying the magnetic field strength are shown in Table II. To vary the magnetic field strength the currents through the inner and outer solenoids were varied proportionally by values suggested by the thruster manufacturer. In previous Russian TAL testing, the optimal current through the magnets was defined as the one which resulted in maximum efficiency and has been found to correspond to a minima in the discharge current.18 In the following figures, the magnetic field is represented by the current through the inner magnet which has been normalized to the nominal operating conditions presented in Table I.

Figure 10 shows the effects of magnetic field strength on discharge current and efficiency at two different flow rates. At a constant voltage of $300 \mathrm{~V}$, lowering the magnetic field caused the current to increase dramatically at normalized inner magnet currents below 0.6 and caused a corresponding decrease in efficiency. At the the lower anode flow rate tested, increasing the current past the nominal value caused the current to increase slightly and then flatten out, while the efficiency steadily decreased. Increasing the normalized current much past 1.2 for anode flow rates of $4.52 \mathrm{mg} / \mathrm{s}$ and above was limited by the heat dissipation capability of the solenoids. Similar to previous Russian experience, at a constant discharge voltage of $300 \mathrm{~V}$ and various anode flow rates, the maximum efficiency corresponded to the magnetic field at which the discharge current was just beginning to increase exponentially.

Figure 11 shows the effects of magnetic field strength on operation at a constant anode flow rate of $4.52 \mathrm{mg} / \mathrm{s}$ and various discharge voltages. For all three voltages tested there appears to be little effect on discharge current at normalized magnet currents above 0.8 , as shown in Figure 11a. The data at discharge voltages of $250 \mathrm{~V}$ and $300 \mathrm{~V}$ are similar. At the lower voltage the curve is shifted upward, and the current rise is more abrupt. The effects on efficiency are shown in Figure 11b. Two different trends are noted, depending on the discharge voltage. At the lowest voltage of $150 \mathrm{~V}$, lowering the normalized magnet current steadily increased the efficiency. At the higher voltages of $250 \mathrm{~V}$ and $300 \mathrm{~V}$, 
the efficiency is essentially constant at normalized inner magnet currents from 0.7 to 1.2. Below 0.7 the efficiency begins to drop. The scatter in the $300 \mathrm{~V}$ data at the normalized inner magnet current of 1.2 is due to the fact that the three points were taken at various outer magnet currents to investigate the effect of changing the inner/outer magnet current proportion. As noted in Table II, the highest outer magnet current caused the efficiency to drop. At low discharge voltages the maximum efficiency does not correspond to the magnetic field which provides a discharge current minima.

\section{EFFECTS OF FACILITY PRESSURE}

The effects of facility pressure on performance were investigated at the nominal thruster operating condition of 4.52 $\mathrm{mg} / \mathrm{s}$ anode flow rate, $0.99 \mathrm{mg} / \mathrm{s}$ cathode flow rate, and $300 \mathrm{~V}$ discharge voltage. The thrust and current were monitored as the pressure was allowed to increase by turning off the diffusion pumps. The effects of pressure on current are shown in Figure 12. No change in thrust was noted from a pressure of $0.00028 \mathrm{~Pa}\left(2.1 \times 10^{-6}\right.$ torr $)$ to $0.00042 \mathrm{~Pa}\left(3.2 \times 10^{-6}\right.$ torr $)$, but the current decreased slightly from 4.09 A to $4.05 \mathrm{~A}$. At that point pumping was provided solely by the helium cryopumping system. Xenon was bled into the facility to increase the pressure from $0.00042 \mathrm{~Pa}\left(3.2 \times 10^{-6}\right.$ torr $)$ to $0.0075 \mathrm{~Pa}\left(5.6 \times 10^{-5}\right.$ torr $)$. In this test the current increased $4 \%$ from $4.07 \mathrm{~A}$ to $4.23 \mathrm{~A}$, and the thrust increased by $2 \mathrm{mN}$, equivalent to approximately $2 \%$. Similar results were noted for a lower cathode flow rate of $0.5 \mathrm{mg} / \mathrm{s}$. For the conditions tested, the facility pressure appears to have little affect on performance; however, the effects on lifetime and plume characteristics are yet to be determined.

At a constant cathode flow rate, the discharge current is a linear function of anode flow rate. The Table I data taken at $300 \mathrm{~V}$ show that for anode flow rates between $2.5 \mathrm{mg} / \mathrm{s}$ to $7.0 \mathrm{mg} / \mathrm{s}$, a $1 \mathrm{mg} / \mathrm{s}$ change in anode flow rate results in a $1.16 \mathrm{~A}$ change in discharge current. With an assumption of a background gas temperature of $300 \mathrm{~K}$ and a discharge area equivalent to the area between the discharge chamber walls, the ingested mass was estimated using kinetic theory at the various pressures tested. Assuming all the ingested flow is added to the anode flow, the $1.16 \mathrm{~A}$ change in discharge current per a $1 \mathrm{mg} / \mathrm{s}$ change in anode propellant can used to predict the increase in discharge current due to ingested mass. However, this causes the effect to be underestimated by a factor of two. One possible explanation is that the effective area of the discharge was similarly underestimated and that the discharge extends significantly past the exit plane of the thruster.

\section{COMPARISONS WITH \\ THE SPT-100}

Performance data were obtained at various cathode flow fractions at a constant anode flow rate of $4.52 \mathrm{mg} / \mathrm{s}$ and a constant voltage of $300 \mathrm{~V}$ and are contained in Table I. At the nominal power level of 1.3 $\mathrm{kW}$, as the cathode flow fraction was decreased from 0.3 to 0.08 the specific impulse increased from 1270 to 1600 with a corresponding efficiency increase from 0.39 to 0.48 . Figure 13 provides plots of specific impulse and efficiency versus cathode flow fraction for both the TAL D-55 and the SPT-100. The performance parameters were calculated both by using the total mass flow and by excluding the cathode mass flow. The performance cost of the flow through the cathode can be readily calculated by subtracting the two curves. The trends for the two thrusters appear identical.

Figure 14 shows comparisons of the specific impulse and efficiency as functions of power for both the TAL D-55 and the SPT-100 at a constant discharge voltage of $300 \mathrm{~V}$. The performance data for the SPT100 were taken from Ref. 2. Both thrusters were tested in the same facility and at similar high vacuum conditions. The SPT data were taken at a lower cathode flow fraction than the TAL. For comparison, the data was normalized by excluding the 
cathode flow in the calculation of the performance parameters. Once normalized, it appears that the TAL and SPT performance are similar at a given power level. In both cases the performance steadily increased with power, hence current, given the constant voltage.

\section{CONCLUDING REMARKS}

Parametric performance testing of a Russian Thruster with Anode Layer was completed over a wide range of operating conditions. Power processing was provided by commercial power supplies. Currentvoltage characteristics at various flow rates showed that the current was insensitive to voltage above the nominal $300 \mathrm{~V}$ operating condition, but increased dramatically at lower voltages.

At the nominal operating power level of 1.3 $\mathrm{kW}$ with a discharge voltage of $300 \mathrm{~V}$, the specific impulse was measured to be $1600 \mathrm{~s}$ with an efficiency of 0.48 . Over the 0.3 to $2.1 \mathrm{~kW}$ power range investigated, direct thrust measurements showed that the efficiency improved with increases in propellant flow rate. At a constant propellant flow rate the efficiency steadily increased with specific impulse until a maximum was reached and then remained constant. Increases in the magnetic field strength, accomplished by increasing the electromagnet current, past the nominal value had little effect on performance. Decreasing the magnet current below $70 \%$ of nominal caused an increase in current and affected the efficiency. The facility pressure had little effect on the thrust and increased the current level by approximately $4 \%$ over a facility background pressure range of $0.0003 \mathrm{~Pa} \quad\left(2 \times 10^{-6}\right.$ torr $)$ to $0.008 \mathrm{~Pa}$ $\left(6 \times 10^{-5}\right.$ torr). The determination of the trade-offs between performance, component lifetime, and plume divergence is on-going.

Comparisons with the SPT-100 showed similar efficiency and specific impulse at the $0.9 \mathrm{~kW}-1.5 \mathrm{~kW}$ power range where comparable data existed.

\section{ACKNOWLEDGEMENTS}

The authors would like to acknowledge Dr. Leonard H. Caveny (BMDO/IST) for support of this work and Dr. Valery I. Garkusha and Dr. Alexander V. Semenkin of the Central Research Institute for Machine Building (TsNIIMASH) in Kaliningrad, Moscow Region, Russia for taking the time to come to NASA LeRC to help with the performance evaluation. Thanks also go to Mr. John A. Hamley of NASA LeRC for setting up the power system to operate the thruster.

\section{REFERENCES}

1. Brophy, J.R., et al., "Performance of the Stationary Plasma Thruster: SPT-100," AIAA-92-3155, July, 1992.

2. Sankovic, J.M., et al., "Performance Evaluation of the Russian SPT-100 Thruster at NASA LeRC," IEPC-93094, Proceedings of the 23rd International Electric Propulsion Conference, September 1993 (also NASA TM 106401).

3. Hamley, J.A., et al., "Power Electronics Development for the SPT-100 Thruster," IEPC-93-044, Proceedings of the $23 \mathrm{rd}$ International Electric Propulsion Conference, September 1993 (also NASA TM 106488).

4. Pencil, E.J., "Far-Field Plume Sputtering Characterization of the Stationary Plasma Thruster (SPT100)," IEPC-93-098, Proceedings of the $23 \mathrm{rd}$ International Electric Propulsion Conference, September 1993 (also NASA TM 106464).

5. Manzella, D.A., "Stationary Plasma Thruster Plume Emissions," IEPC-93-097, Proceedings of the 23rd International Electric Propulsion Conference, September 1993 (also NASA CR 194471). 
6. Manzella, D. A., "Stationary Plasma Thruster Ion Velocity Distribution," AIAA 94-3141, Proposed paper for the 30th Joint Propulsion Conf., June 1994.

7. Myers, R.M. and Manzella, D.A., "Stationary Plasma Thruster Plume Characteristics," IEPC-93-096, Proceedings of the $23 \mathrm{rd}$ International Electric Propulsion Conference, September 1993 (also NASA CR 194454).

8. Sarmiento, C.J., NASA Lewis Research Center, Private Communication, July 1993.

9. Day, M, et al., "SPT-100 Subsystem Development Status and Plan," AIAA 94-2853, Proposed paper for the 30th Joint Propulsion Conf., June 1994.

10. Garner, C., et al., "Performance Evaluation and Life Testing of the SPT-100," IEPC-93-091, Proceedings of the 23rd International Electric Propulsion Conference, September 1993.

11. Lyapin, E.A., et al., "Anode Layer Thruster: State-of-the-Art and Perspectives," IEPC-93-228, Proceedings of the 23rd International Electric Propulsion Conference, September 1993.

12. Kaufman, H.R.,"Technology of Closed-Drift Thrusters," AIAA Journal, Vol. 23, No.1, pp. 78-87, January 1985.

13. Patterson, M.J., et al., "Plasma Contactor Technology for Space Station Freedom," AIAA 93-2228, July 1993 (also NASA TM 106291).

14. Grisnik, S.P. and Parkes, J.E., "A Large, High Vacuum, High Pumping Speed Space Simulation Chamber for Electric Propulsion," IEPC-93-151, Proceedings of the 23rd International Electric Propulsion Conference, September 1993.

15. Sovey, J.S., et al., "Test Facilities for High Power Electric Propulsion," J. Propulsion and Power, Vol. 10, No. 1, Jan.-Feb. 1994.

16. Haag, T.M. and Curran, F.M., "Arcjet Starting Reliability: A Multistart Test," AIAA 87-1061 (also NASA TM 89867), May 1987.

17. Holanda, R.,"Sensitivity of HotCathode Ionization Vacuum Gages in Several Gases," NASA TN D6815, July 1972.

18. Semenkin, A., Central Research Insititute of Machine Building (TsNIIMASH), Kaliningrad, Moscow Region, Russia, Private Communication, December 1993. 


\begin{tabular}{|c|c|c|c|c|c|c|c|c|c|c|c|c|c|c|c|c|}
\hline $\begin{array}{l}\text { DISCHAAGE } \\
\text { VOLTAGE }\end{array}$ & $\begin{array}{l}\text { DSCAARGE } \\
\text { CARBENT }\end{array}$ & $\begin{array}{l}\text { KEIPER } \\
\text { VOLTAGE }\end{array}$ & $\begin{array}{l}\text { KEGG } \\
\text { CUPRENT }\end{array}$ & $\begin{array}{l}\text { OUIG } \\
\text { MAGNET } \\
\text { VOLTAGE }\end{array}$ & $\begin{array}{l}\text { OUIER } \\
\text { MAGNET } \\
\text { CUPREVT }\end{array}$ & $\begin{array}{l}\text { INNER } \\
\text { MAGNET } \\
\text { VOLIAGE }\end{array}$ & $\begin{array}{l}\text { INNER } \\
\text { MAGNET } \\
\text { CUARENT }\end{array}$ & $\begin{array}{c}\text { ANOOE } \\
\text { MASS FLOW }\end{array}$ & $\begin{array}{c}\text { CATHOOE } \\
\text { MASS FLOW }\end{array}$ & \begin{tabular}{c|} 
TOTAL \\
MASS FLOW
\end{tabular} & PRESSUAE & $\begin{array}{c}\text { GAOUNO- } \\
\text { CAIHODE } \\
\text { POTENTIAL } \\
\end{array}$ & THRUST & $\begin{array}{l}\text { SPECIFIC } \\
\text { IMPULSE }\end{array}$ & POWER & EFFCIENCY \\
\hline$v$ & A & $\mathrm{v}$ & A & $\mathrm{V}$ & A & $\mathrm{v}$ & $A$ & $\mathrm{mg} / \mathrm{s}$ & $\mathrm{mg} / \mathrm{s}$ & $\mathrm{mg} / \mathrm{s}$ & $\mathrm{Pa}$ & $\mathrm{v}$ & $\mathrm{mN}$ & 3 & w & \\
\hline 300.1 & 2.12 & 13.2 & 2.0 & 2.9 & 0.9 & 3.0 & 2.3 & 2.65 & 1.0 & 3.6 & 0.00023 & 12.3 & 39.8 & 1115 & $64 \theta$ & 0.337 \\
\hline 350.2 & 2.09 & 13.0 & 2.0 & 2.8 & 0.8 & 3.0 & 2.3 & 2.65 & 1.0 & 3.6 & 0.00021 & 12.2 & 42.6 & 1193 & 741 & 0.336 \\
\hline 400.4 & 2.07 & 12.9 & 2.0 & 2.9 & 0.9 & 3.1 & 2.3 & 2.65 & 1.0 & 3.6 & 0.00021 & 11.8 & 45.5 & 1274 & 839 & 0.339 \\
\hline 450.0 & 2.05 & 12.8 & 2.0 & 3.0 & 1.0 & 3.2 & 2.3 & 2.65 & 1.0 & 3.6 & 0.00021 & 11.6 & 48.2 & 1350 & $\begin{array}{c}933 \\
1030\end{array}$ & $\begin{array}{l}0.342 \\
0.340\end{array}$ \\
\hline 500.0 & 2.04 & 12.7 & 2.0 & 3.0 & 0.9 & 3.3 & 2.3 & 2.65 & 1.0 & 3.6 & 0.00021 & - & 50.5 & $\begin{array}{l}1414 \\
1064\end{array}$ & & $\begin{array}{l}0.340 \\
0.311\end{array}$ \\
\hline 300.4 & 2.08 & 13.0 & 2.0 & 3.0 & 1.0 & 3.3 & 2.3 & $\begin{array}{l}2.65 \\
2.65\end{array}$ & $\begin{array}{l}1.0 \\
1.0\end{array}$ & $\begin{array}{l}3.6 \\
3.6\end{array}$ & $\begin{array}{l}0.00021 \\
0.00021\end{array}$ & $\begin{array}{l}12.2 \\
12.0\end{array}$ & $\begin{array}{l}38.0 \\
34.2\end{array}$ & $\begin{array}{c}1064 \\
958\end{array}$ & 548 & 0.293 \\
\hline $\begin{array}{l}249.9 \\
200.0\end{array}$ & $\begin{array}{l}2.15 \\
2.27\end{array}$ & $\begin{array}{l}12.9 \\
12.8\end{array}$ & $\begin{array}{l}2.0 \\
2.0\end{array}$ & $\begin{array}{l}3.0 \\
3.1\end{array}$ & $\begin{array}{l}1.0 \\
1.0\end{array}$ & $\begin{array}{l}3.4 \\
3.5\end{array}$ & $\begin{array}{l}2.3 \\
2.3\end{array}$ & $\begin{array}{l}2.65 \\
2.65\end{array}$ & 1.0 & $\begin{array}{l}3.0 \\
3.6\end{array}$ & 0.00023 & 11.6 & 30.1 & 843 & 465 & 0.268 \\
\hline 149.5 & 2.52 & 12.7 & 2.0 & 3.2 & 1.0 & 3.6 & 2.3 & 2.65 & 1.0 & 3.6 & 0.00023 & 10.2 & 25.3 & 700 & 388 & 0.227 \\
\hline 99.7 & 2.97 & 12.5 & 2.0 & 3.2 & 1.0 & 3.6 & 2.3 & 2.65 & 1.0 & 3.6 & 0.00023 & 7.9 & 18.6 & 521 & 307 & 0.155 \\
\hline 301.0 & 2.00 & 12.8 & 2.0 & 3.2 & 0.9 & 3.7 & 2.3 & 2.65 & 1.0 & 3.8 & 0.00023 & 12.8 & 39.3 & 1101 & 641 & 0.331 \\
\hline 300.3 & 3.08 & 12.2 & 2.0 & 3.1 & 1.0 & 4.7 & 3,1 & 3.57 & 1.0 & 4.6 & 0.00027 & 12.6 & 59.1 & 1320 & 942 & 0.406 \\
\hline 350.2 & 3.05 & 12.1 & 2.0 & 3.1 & 1.0 & 4.9 & 3.1 & 3.57 & 1.0 & 4.6 & 0.00027 & 12.4 & 63.5 & 1418 & 1086 & 0.407 \\
\hline 399.7 & 3.02 & 12.1 & 2.0 & 3.2 & 1.0 & 5.0 & 3.1 & 3.57 & 1.0 & 4.6 & 0.00027 & 11.8 & 67.0 & 1509 & 1226 & 0.408 \\
\hline 451.0 & 2.94 & 11.9 & 2.0 & 3.2 & 1.0 & 5.2 & 3.1 & 3.57 & 1.0 & 4.6 & 0.00027 & 11.5 & 70.4 & 1572 & 1345 & 0.404 \\
\hline 300.5 & 2.88 & 12.0 & 2.0 & 3.3 & 1.0 & 5.6 & 3.1 & 3.57 & 1.0 & 4.6 & 0.00027 & 12.4 & 58.5 & 1261 & 818 & 0.380 \\
\hline 250.3 & 3.01 & 12.0 & 2.0 & 3.3 & 1.0 & 5.7 & 3.1 & 3.57 & 1.0 & 4.6 & 0.00027 & 12.5 & 51.1 & 1141 & 774 & 0.369 \\
\hline 190.8 & 3.07 & 12.0 & 2.0 & 3.3 & 1.0 & 5.7 & 3.1 & 3.57 & 1.0 & 4.6 & 0.00027 & 11.8 & 44.5 & 994 & 634 & 0.342 \\
\hline 150.2 & 3.27 & 12.0 & 2.0 & 3.4 & 1.0 & 5.6 & 3.1 & 3.57 & 1.0 & 4.6 & 0.00027 & 10.2 & 38.6 & 862 & 512 & 0.319 \\
\hline 290.8 & 3.05 & 12.0 & 2.0 & 3.5 & 1.0 & 5.8 & 3.1 & 3.57 & 1.0 & 4.6 & & 12.5 & 58.3 & 1302 & 830 & 0.398 \\
\hline 300.1 & 4.08 & 11.8 & 2.0 & 3.5 & 0.9 & 7.9 & 4.0 & 4.52 & 1.0 & 5.5 & 0.00031 & 12.8 & 79.6 & 1472 & 1282 & 0.455 \\
\hline 349.9 & 4.08 & 11.7 & 2.0 & 3.6 & 0.8 & 8.0 & 4.0 & 4.52 & 1.0 & 5.5 & 0.00031 & 12.5 & 85.9 & 1588 & 1456 & 0.460 \\
\hline 400.0 & 4.02 & 11.7 & 2.0 & 3.6 & 0.8 & 8.5 & 1.2 & 4.52 & 1.0 & 5.5 & 0.00031 & 12.4 & 91.4 & 1690 & 1647 & 0.460 \\
\hline $\begin{array}{l}300.8 \\
450.0\end{array}$ & 4.10 & 11.8 & 2.0 & 3.7 & 0.8 & 8.8 & 4.2 & 4.52 & 1.0 & 5.5 & 0.00031 & 12.2 & 78.2 & 1465 & 1274 & 0.447 \\
\hline $\begin{array}{l}150.0 \\
240.7\end{array}$ & 3.80 & 11.8 & 2.0 & 3.7 & 0.0 & 8.0 & 4.2 & 4.52 & 1.0 & 5.5 & 0.00031 & 12.1 & 87.3 & 1789 & 1836 & 0.468 \\
\hline $\begin{array}{l}240.7 \\
200.3\end{array}$ & 4.10 & 11.8 & 2.0 & 3.8 & 0.9 & 0.1 & 4.2 & 4.52 & 1.0 & 5.5 & 0.00031 & 12.0 & 70.5 & 1304 & 1065 & 0.423 \\
\hline $\begin{array}{l}200.3 \\
148.8\end{array}$ & 4.24 & 11.7 & 2.0 & 3.8 & 0.9 & 9.2 & 4.2 & 4.52 & 1.0 & 5.5 & 0.00031 & 11.3 & 61.9 & 1145 & 891 & $\begin{array}{l}0.390 \\
0.330\end{array}$ \\
\hline $\begin{array}{l}149.8 \\
302.3\end{array}$ & $\begin{array}{l}4.42 \\
4.10\end{array}$ & $\begin{array}{l}11.7 \\
11.8\end{array}$ & $\begin{array}{l}2.0 \\
2.0\end{array}$ & $\begin{array}{l}3.9 \\
3.8\end{array}$ & $\begin{array}{l}0.9 \\
0.8\end{array}$ & $\begin{array}{l}0.2 \\
0.2\end{array}$ & $\begin{array}{l}4.2 \\
4.2\end{array}$ & $\begin{array}{l}4.52 \\
4.52\end{array}$ & $\begin{array}{l}1.0 \\
1.0\end{array}$ & $\begin{array}{l}5.5 \\
5.5\end{array}$ & $\begin{array}{l}0.00032 \\
0.00031\end{array}$ & $\begin{array}{l}10.1 \\
11.9\end{array}$ & $\begin{array}{l}50.6 \\
79.2\end{array}$ & $\begin{array}{c}836 \\
1465\end{array}$ & $\begin{array}{c}705 \\
1282\end{array}$ & $\begin{array}{l}0.330 \\
0.444\end{array}$ \\
\hline 289.8 & $5.2 \theta$ & 1.5 & 2.0 & 5.0 & & & & 5.50 & & & & & & & 1634 & \\
\hline 350.5 & $\begin{array}{l}5.28 \\
5.24\end{array}$ & 11.4 & 2.0 & 5.0 & $\begin{array}{l}1.2 \\
1.2\end{array}$ & $\begin{array}{l}9.7 \\
8.8\end{array}$ & 4.4 & $\begin{array}{l}5.50 \\
5.50\end{array}$ & $\begin{array}{l}1.0 \\
1.0\end{array}$ & 6.5 & 0.00035 & $\begin{array}{ll}11.8 \\
120\end{array}$ & $\begin{array}{l}101.3 \\
110.1\end{array}$ & $\begin{array}{l}1581 \\
1730\end{array}$ & $\begin{array}{l}1634 \\
1885\end{array}$ & $\begin{array}{l}0.484 \\
0.495\end{array}$ \\
\hline 400.7 & 5.10 & 11.5 & 2.0 & 5.1 & 1.2 & $\begin{array}{l}9.8 \\
8.8\end{array}$ & 4.4 & $\begin{array}{l}5.50 \\
3.50\end{array}$ & $\begin{array}{l}1.0 \\
1.0\end{array}$ & $\begin{array}{l}6.5 \\
6.5\end{array}$ & 0.00035 & $\begin{array}{l}12.0 \\
12.2\end{array}$ & 117.8 & 1850 & 2128 & \\
\hline 248.8 & 5.32 & 11.5 & 2.0 & 5.1 & 1.2 & $\begin{array}{l}8.8 \\
9.8\end{array}$ & $\begin{array}{l}4.4 \\
4.4\end{array}$ & 5.50 & 1.0 & $\begin{array}{l}6.5 \\
6.5\end{array}$ & 0.00035 & $\begin{array}{l}72.2 \\
11.6\end{array}$ & 81.0 & 1428 & 1378 & 0.463 \\
\hline 199.3 & 5.50 & 11.2 & 2.0 & 5.2 & 1.1 & 10.0 & 4.4 & 5.50 & 1.0 & 6.5 & 0.00036 & 10.8 & 80.0 & 1257 & 1146 & 0.430 \\
\hline 150.4 & 5.65 & 11.2 & 2.0 & 5.2 & 1.2 & 10.0 & 4.4 & 5.50 & 1.0 & 6.5 & 0.00037 & 8.8 & 64.8 & 1018 & 890 & 0.360 \\
\hline 300.0 & 5.31 & 11.3 & 2.0 & 5.2 & 1.2 & 10.0 & 4.4 & 5.50 & 1.0 & 6.5 & 0.00035 & 11.8 & 102.1 & 1804 & 1643 & 0.489 \\
\hline 300.1 & 5.30 & 0.0 & 0.0 & 5.3 & 1.2 & 10.0 & 4.4 & 5.50 & 1.0 & 6.5 & & 12.1 & 100.7 & 1582 & 1640 & 0.476 \\
\hline 300.4 & 4.10 & 0.0 & 0.0 & 4.3 & 0.8 & 8.6 & 4.2 & 4.52 & 1.0 & 5.5 & & 12.3 & 78.6 & 1454 & 1276 & 0.439 \\
\hline 299.8 & 3.04 & 0.0 & 0.0 & 4.3 & 0.8 & 7.4 & 3.3 & 3.57 & 1.0 & 4.6 & & 11.9 & 57.8 & 1283 & 940 & 0.391 \\
\hline 289.4 & 2.07 & 0.0 & 0.0 & 4.3 & 0.8 & 5.3 & 2.5 & 2.65 & 1.0 & 3.6 & & 12.2 & 38.1 & 1067 & 637 & 0.313 \\
\hline 250.5 & 0.88 & 12.0 & 2.0 & 5.1 & 1.1 & 8.5 & 1.3 & 0.69 & 0.5 & 7.2 & 0.00035 & 12.6 & 112.3 & 1598 & 1771 & 0.497 \\
\hline 289.4 & 6.83 & 12.1 & 2.0 & 5.2 & 1.2 & 8.7 & 4.3 & 0.69 & 0.5 & 7.2 & 0.00037 & 13.1 & 126.0 & 1795 & 2093 & 0.530 \\
\hline 299.0 & 0.85 & 11.2 & 2.0 & 3.2 & 1.2 & 8.8 & 4.3 & 0.69 & 1.0 & 7.7 & 0.00038 & 12.2 & 128.6 & 1706 & 2087 & 0.513 \\
\hline 300.4 & 4.08 & 12.3 & 2.0 & 4.0 & 0.8 & 9.5 & 4.2 & 4.52 & 1.0 & 5.5 & 0.00031 & 12.8 & 78.1 & 1444 & 1272 & 0.435 \\
\hline 300.7 & 4.00 & 12.0 & 2.0 & 4.0 & 0.0 & 9.5 & 4.2 & 4.52 & 0.8 & 5.3 & 0.00029 & 14.6 & 77.3 & 1487 & 1273 & 0.443 \\
\hline 300.6 & 4.08 & 13.7 & 2.0 & 4.0 & 0.9 & 8.5 & 4.2 & 4.52 & 0.6 & 5.1 & 0.00028 & 13.5 & 77.5 & 1552 & 1273 & 0.464 \\
\hline 300.7 & 4.00 & 14.4 & 2.0 & 4.0 & 0.9 & 9.5 & 4.2 & 4.52 & 0.4 & 4.8 & 0.00027 & 14.3 & 76.8 & 1605 & 1273 & 0.475 \\
\hline 299.9 & 4.10 & 12.1 & 2.0 & 4.1 & 0.9 & 8.5 & 4.2 & 4.52 & 1.5 & 6.0 & 0.00033 & 10.3 & 80.8 & 1365 & 1281 & 0.420 \\
\hline 280.5 & 4.20 & 12.0 & 2.0 & 4.1 & 0.8 & 8.5 & 4.2 & 4.52 & 2.1 & 8.6 & 0.00037 & 10.5 & 82.0 & 1272 & 1302 & 0.383 \\
\hline 288.8 & 4.10 & 0.0 & 0.0 & 4.1 & 0.8 & 8.5 & 4.2 & 4.52 & 2.1 & 6.6 & 0.00037 & 9.8 & 80.8 & 1254 & 1291 & 0.385 \\
\hline 300.5 & 4.10 & 0.0 & 0.0 & 4.1 & 0.8 & 8.5 & 4.2 & 4.52 & 1.5 & 6.0 & 0.00035 & 11.8 & 79.1 & 1335 & 1276 & 0.406 \\
\hline 300.8 & 4.10 & 0.0 & 0.0 & 4.1 & 0.8 & 0.5 & 4.2 & 4.52 & 1.0 & 5.5 & 0.00031 & 12.3 & 78.2 & 1446 & 1276 & 0.435 \\
\hline 300.7 & 4.00 & 0.0 & 0.0 & 4.1 & 0.0 & 0.5 & 4.2 & 4.52 & 0.8 & 5.3 & 0.00029 & 12.8 & 77.4 & 1488 & 1274 & 0.444 \\
\hline 300.7 & 4.09 & 0.0 & 0.0 & 4.1 & 0.8 & 9.6 & 4.2 & 4.52 & 0.0 & 5.1 & 0.00028 & 14.1 & 77.4 & 1550 & 1274 & 0.462 \\
\hline 300.7 & 4.08 & 0.0 & 0.0 & 4.1 & 0.9 & 8.8 & 4.2 & 4.52 & 0.4 & 4.8 & 0.00027 & 100 & $\begin{array}{l}76.3 \\
75.3\end{array}$ & 1594 & 1271 & 0.469 \\
\hline 300.9 & 4.10 & 0.0 & 0.0 & 4.1 & 0.8 & 9.6 & 4.2 & 4.52 & 0.3 & 4.8 & 0.00027 & 19.0 & 75.3 & 1608 & 1278 & 0.465 \\
\hline
\end{tabular}

Table I. - TAL performance at various power levels 


\begin{tabular}{|c|c|c|c|c|c|c|c|c|c|c|c|c|c|c|c|c|}
\hline $\begin{array}{l}\text { DISCHAAGE } \\
\text { VOLTAGE }\end{array}$ & $\begin{array}{l}\text { DISCHARGE } \\
\text { CUPRENT }\end{array}$ & $\begin{array}{l}\text { KEPPEA } \\
\text { VOLTAGE }\end{array}$ & $\begin{array}{l}\text { KEAPG } \\
\text { CUPRENT }\end{array}$ & $\begin{array}{l}\text { OUIG } \\
\text { MAGNET } \\
\text { VOLTAGE }\end{array}$ & $\begin{array}{l}\text { OUIER } \\
\text { MAGNET } \\
\text { CURRENT }\end{array}$ & $\begin{array}{l}\text { INNER } \\
\text { MAGNET } \\
\text { VOLTAGE }\end{array}$ & $\begin{array}{l}\text { INNER } \\
\text { MMGNET } \\
\text { CURPBNT }\end{array}$ & $\begin{array}{c}\text { ANOOE } \\
\text { MASS FLOW }\end{array}$ & $\begin{array}{l}\text { CANHOOE } \\
\text { MASS FLOW }\end{array}$ & $\begin{array}{c}\text { TOTAL } \\
\text { MASS FLOW }\end{array}$ & PRESSUAE & $\begin{array}{c}\text { GAOUND } \\
\text { CATHODE } \\
\text { POTENTIAL } \\
\end{array}$ & THRUST & $\begin{array}{l}\text { SPECIFIC } \\
\text { IMPULSE }\end{array}$ & POWEA & EFACIENCY \\
\hline v & A & $\mathrm{v}$ & A & $v$ & $A$ & $\mathrm{v}$ & $A$ & $\mathrm{mg} / \mathrm{s}$ & $\mathrm{mg} / \mathrm{s}$ & $\mathrm{mg} / \mathrm{s}$ & $P_{A}$ & $\mathrm{v}$ & $\mathrm{mN}$ & 8 & $w$ & \\
\hline 301.3 & 4.12 & 13.3 & 2.1 & 2.6 & $0 . \theta$ & 7.9 & 4.1 & 4.52 & 0.89 & 5.5 & 0.00028 & 15.0 & 78.6 & 1454 & 1276 & 0.439 \\
\hline 300.6 & 4.11 & 13.3 & 2.0 & 2.3 & 0.7 & 7.2 & 3.8 & 4.52 & $0.8 \theta$ & 5.5 & 0.00028 & 15.2 & 77.9 & 1441 & 1264 & 0.435 \\
\hline 300.3 & 4.14 & 13.3 & 2.0 & 2.1 & 0.7 & 6.3 & 3.4 & 4.52 & 0.89 & 5.5 & 0.00028 & 15.2 & 77.6 & 1435 & 1266 & 0.432 \\
\hline 290.6 & 4.21 & 13.2 & 2.0 & 1.8 & 0.0 & 5.3 & 2.9 & 4.52 & 0.88 & 5.5 & 0.00028 & 15.0 & 77.5 & 1433 & 1278 & 0.426 \\
\hline 300.2 & 5.20 & 12.5 & 1.3 & 1.6 & 0.5 & 4.4 & 2.4 & 4.52 & 0.89 & 5.5 & 0.00028 & 11.1 & 79.2 & 1465 & 1573 & 0.362 \\
\hline 300.0 & 4.07 & 13.3 & 2.0 & 2.8 & 0.0 & 8.0 & 4.2 & 4.52 & 0.08 & 5.5 & 0.00028 & 15.2 & 77.1 & 1426 & 1257 & 0.429 \\
\hline 300.2 & 4.05 & 13.3 & 2.0 & 3.2 & 1.0 & 10.2 & 5.0 & 4.52 & 0.80 & 5.5 & 0.00028 & 15.3 & 77.0 & 1424 & 1270 & 0.424 \\
\hline 300.3 & 4.03 & 13.0 & 2.1 & 5.0 & 1.4 & 10.7 & 5.1 & 4.52 & 0.89 & 5.5 & 0.00028 & 13.4 & 76.6 & 1417 & 1271 & 0.419 \\
\hline 300.1 & 4.00 & 12.8 & 2.1 & 6.6 & 1.0 & 10.8 & 5.0 & 4.52 & 0.89 & 5.5 & 0.00028 & 14.0 & 75.0 & 1387 & 1286 & 0.397 \\
\hline 300.2 & 4.05 & 13.3 & 2.1 & 3.2 & 0.8 & 8.1 & 4.2 & 4.52 & 0.99 & 5.5 & 0.00028 & 14.8 & 77.3 & 1430 & 1257 & 0.431 \\
\hline 208.7 & 2.13 & 14.7 & 2.0 & 3.4 & 0.0 & 4.5 & 2.6 & 2.65 & 0.89 & 3.6 & 0.00020 & 13.3 & 38.6 & 1081 & 653 & 0.313 \\
\hline 300.6 & 2.05 & 14.7 & 2.0 & 2.8 & 0.8 & 3.5 & 2.0 & 2.65 & 0.89 & 3.6 & 0.00020 & 14.7 & 38.4 & 1075 & 826 & 0.324 \\
\hline 300.2 & 2.08 & 14.7 & 2.0 & 2.5 & 0.7 & 3.0 & 1.8 & 2.65 & 0.89 & 3.6 & 0.00020 & 15.8 & 38.1 & 1085 & 034 & 0.331 \\
\hline $289 . \theta$ & 2.13 & 14.7 & 2.0 & 2.2 & 0.0 & 2.6 & 1.5 & 2.65 & 0.98 & 3.6 & 0.00020 & 14.7 & 38.7 & 1112 & 644 & 0.336 \\
\hline 280.0 & 2.30 & 14.6 & 2.0 & 1.7 & 0.4 & 2.2 & 1.3 & 2.05 & 0.89 & 3.6 & 0.00020 & 13.7 & 39.7 & 1112 & 603 & 0.312 \\
\hline 299.6 & 3.08 & 14.0 & 1.7 & 1.3 & 0.3 & 2.1 & 1.3 & 2.05 & 0.88 & 3.6 & 0.00020 & 10.3 & 40.0 & 1137 & 820 & 0.216 \\
\hline 298.0 & 2.07 & 14.0 & 2.0 & 3.4 & 0.0 & 4.3 & 2.6 & 2.05 & 0.09 & 3.6 & 0.00020 & 13.8 & 38.1 & 1087 & 635 & 0.314 \\
\hline 300.1 & 2.31 & 14.4 & 2.0 & 3.8 & 1.0 & 4.8 & 2.8 & 2.65 & 0.89 & 3.6 & 0.00020 & 11.8 & 38.5 & 1078 & 710 & 0.287 \\
\hline 300.2 & 2.45 & 14.4 & 2.0 & 4.2 & 1.1 & 5.4 & 3.0 & 2.65 & 0.89 & 3.6 & 0.00020 & 11.2 & 38.7 & 1084 & 756 & 0.272 \\
\hline 300.2 & 2.45 & 14.2 & 2.0 & 4.6 & 1.1 & 6.0 & 3.2 & 2.65 & $0.9 \theta$ & 3.6 & 0.00020 & 11.6 & 38.4 & 1075 & 780 & 0.266 \\
\hline 300.0 & 2.47 & 14.0 & 2.0 & 5.9 & 1.5 & 7.3 & 3.8 & 2.65 & 0.99 & 3.6 & 0.00020 & 12.1 & 38.4 & 1075 & 777 & 0.261 \\
\hline $28 \theta .0$ & 2.51 & 13.9 & 1.8 & 8.1 & 1.8 & 8.8 & 4.2 & 2.65 & 0.89 & 3.6 & 0.00020 & 12.9 & 38.2 & 1070 & 805 & 0.249 \\
\hline 289.8 & 2.11 & 14.5 & 2.0 & 3.7 & 0.8 & 5.4 & 2.6 & 2.65 & 0.89 & 3.6 & 0.00020 & 13.5 & 38.3 & 1073 & 650 & 0.310 \\
\hline 250.6 & 4.11 & 13.3 & 1.8 & 3.8 & 0.8 & 8.2 & 4.2 & 4.52 & 0.80 & 5.5 & 0.00028 & 15.1 & 68.2 & 1280 & 1072 & 0.405 \\
\hline 250.7 & 4.11 & 13.3 & 1.8 & 3.2 & 0.7 & 8.1 & 3.8 & 4.52 & 0.80 & 5.5 & 0.00028 & 15.5 & 68.2 & 1280 & 1063 & 0.408 \\
\hline 250.5 & 4.13 & 13.3 & 1.8 & 2.7 & 0.0 & 7.1 & 3.3 & 4.52 & 0.80 & 5.5 & $0.0002 \theta$ & 15.8 & 68.0 & 1276 & 1060 & 0.407 \\
\hline 248.8 & 4.21 & 13.3 & 1.8 & 2.3 & 0.5 & 0.0 & 2.8 & 4.52 & $0.9 \theta$ & 5.5 & 0.00028 & 15.2 & 68.0 & 1276 & 1070 & 0.404 \\
\hline 250.2 & 4.14 & 13.2 & 1.9 & 4.2 & 1.0 & 10.0 & 5.1 & 4.52 & 0.00 & 5.5 & 0.00028 & 15.1 & 68.4 & 1283 & 1085 & 0.398 \\
\hline 150.1 & 4.37 & 13.2 & 2.0 & 3.8 & 0.8 & 0.2 & 4.2 & 4.52 & 0.90 & 5.5 & 0.00031 & 12.4 & 47.4 & 877 & 698 & 0.292 \\
\hline 150.2 & 4.36 & 13.2 & 1.8 & 3.3 & 0.8 & 8.2 & 3.8 & 4.52 & $0.9 \theta$ & 5.5 & 0.00031 & 12.0 & 47.8 & 884 & 688 & 0.301 \\
\hline 150.3 & 4.35 & 13.2 & 1.0 & 2.8 & 0.6 & 7.2 & 3.4 & 4.52 & 0.89 & 5.5 & 0.00031 & 12.8 & 47.8 & 884 & 680 & 0.305 \\
\hline 150.3 & 4.35 & 13.3 & 2.0 & 2.3 & 0.5 & 6.1 & 2.8 & 4.52 & $0.9 \theta$ & 5.5 & 0.00031 & 12.8 & 48.2 & 891 & 673 & 0.313 \\
\hline 150.2 & 4.36 & 13.3 & 2.0 & 2.0 & 0.5 & 5.5 & 2.7 & 4.52 & 0.98 & 5.5 & 0.00031 & 12.7 & 48.4 & 895 & 671 & 0.317 \\
\hline 150.0 & 4.37 & 13.4 & 2.0 & 1.5 & 0.4 & 4.8 & 2.4 & 4.52 & 0.89 & 5.5 & 0.00031 & 12.4 & 48.8 & 903 & 668 & 0.323 \\
\hline 150.4 & 4.57 & 13.3 & 2.0 & 1.1 & 0.3 & 4.4 & 2.3 & 4.52 & 0.89 & 5.5 & 0.00031 & 10.5 & 50.6 & 936 & 698 & 0.333 \\
\hline 150.1 & 4.37 & 13.1 & 2.0 & 3.8 & 0.8 & 8.3 & 4.2 & 4.52 & 0.99 & 5.5 & 0.00031 & 12.3 & 48.0 & 888 & 694 & 0.301 \\
\hline
\end{tabular}

Table II. - Effects of magnetic field strength on TAL performance 


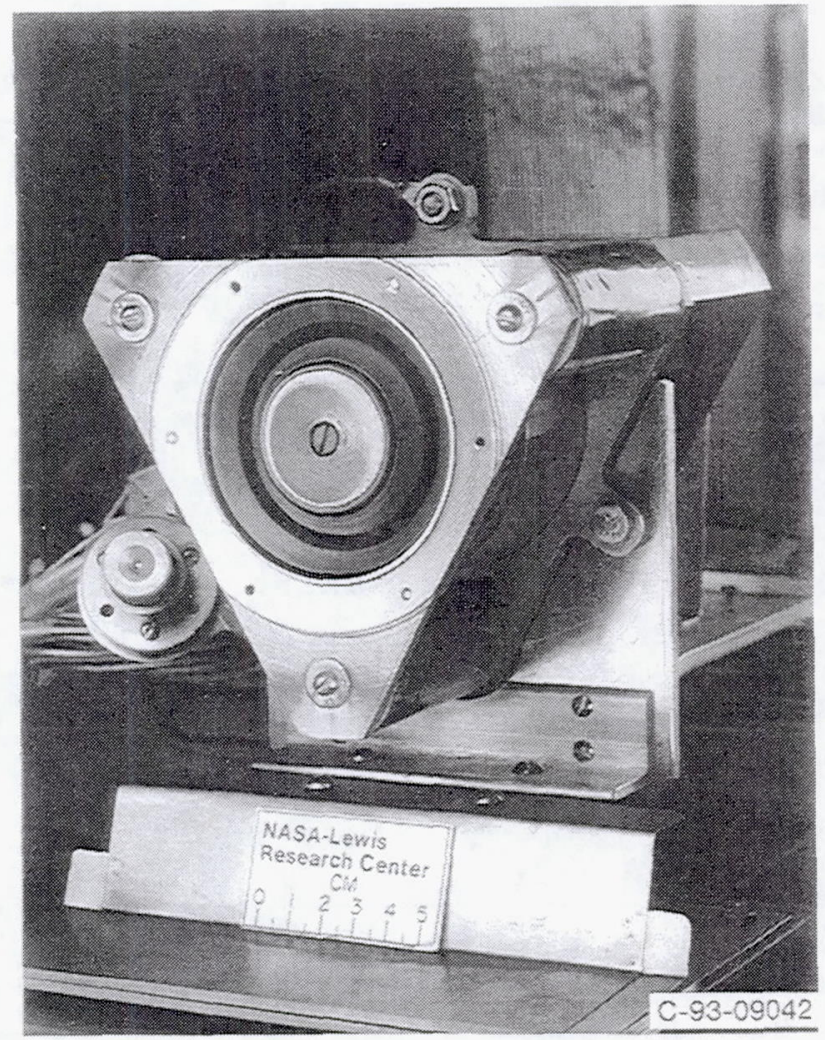

(a) Photograph of TAL model D-55.

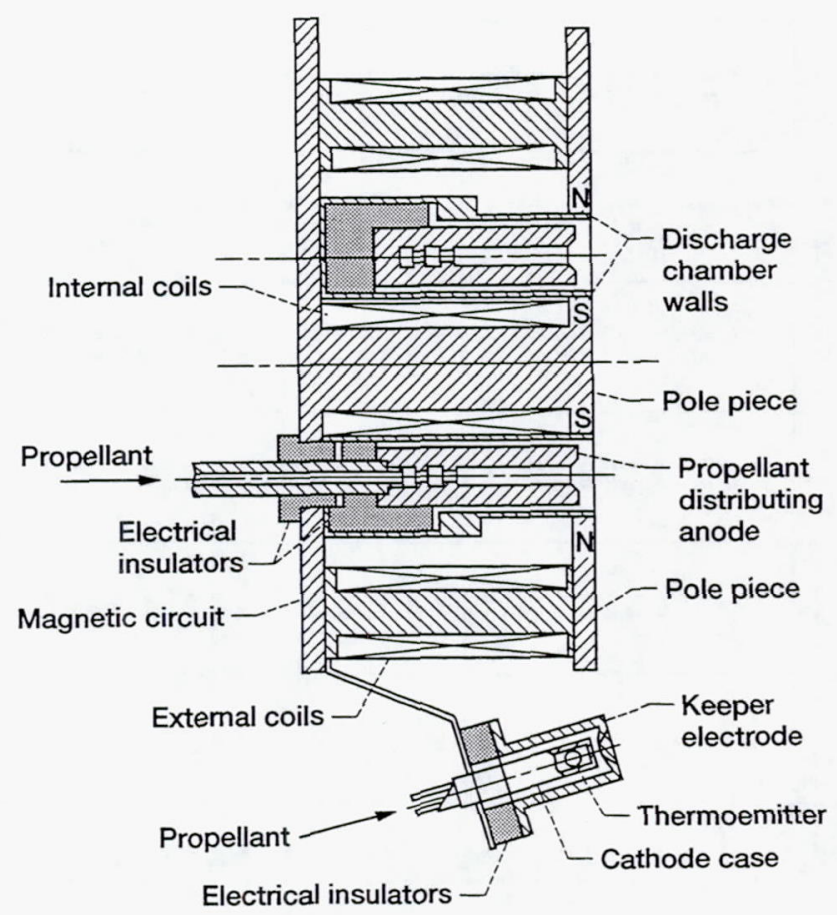

(b) Schematic of TAL.

Figure 1.-Thruster with anode layer (TAL). 

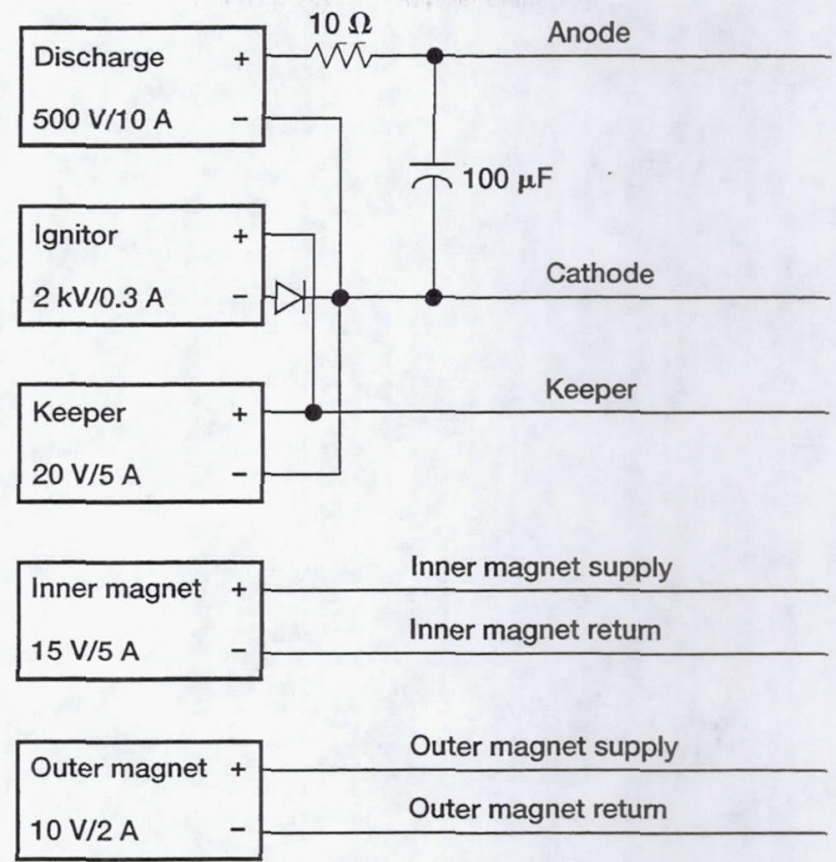

Figure 2.-Schematic of power supplies used to operate TAL.

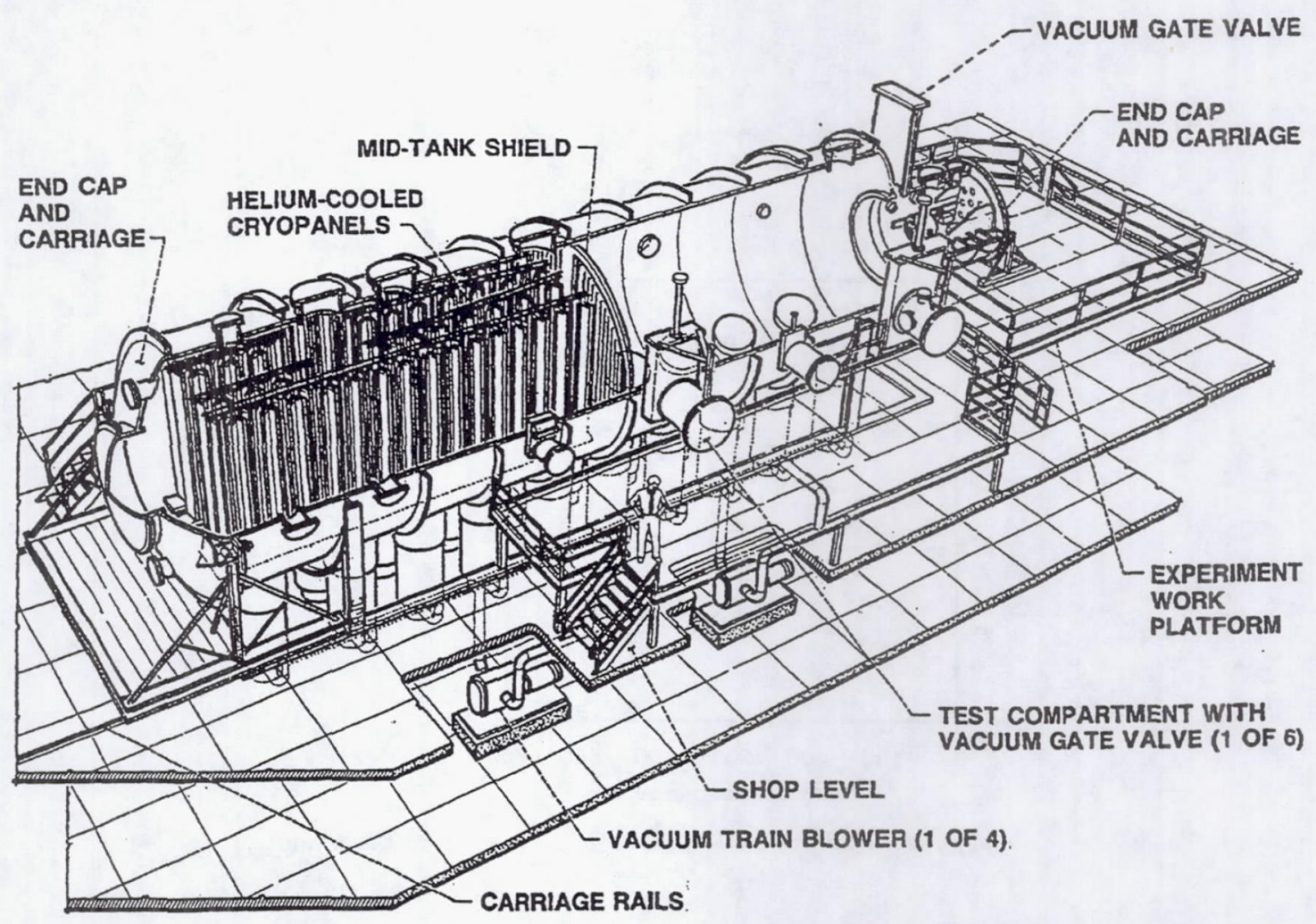

Figure 3.-Tank 5 vacuum facility ( $5 \mathrm{~m}$ diameter $\times 20 \mathrm{~m}$ overall) at NASA Lewis Research Center. 


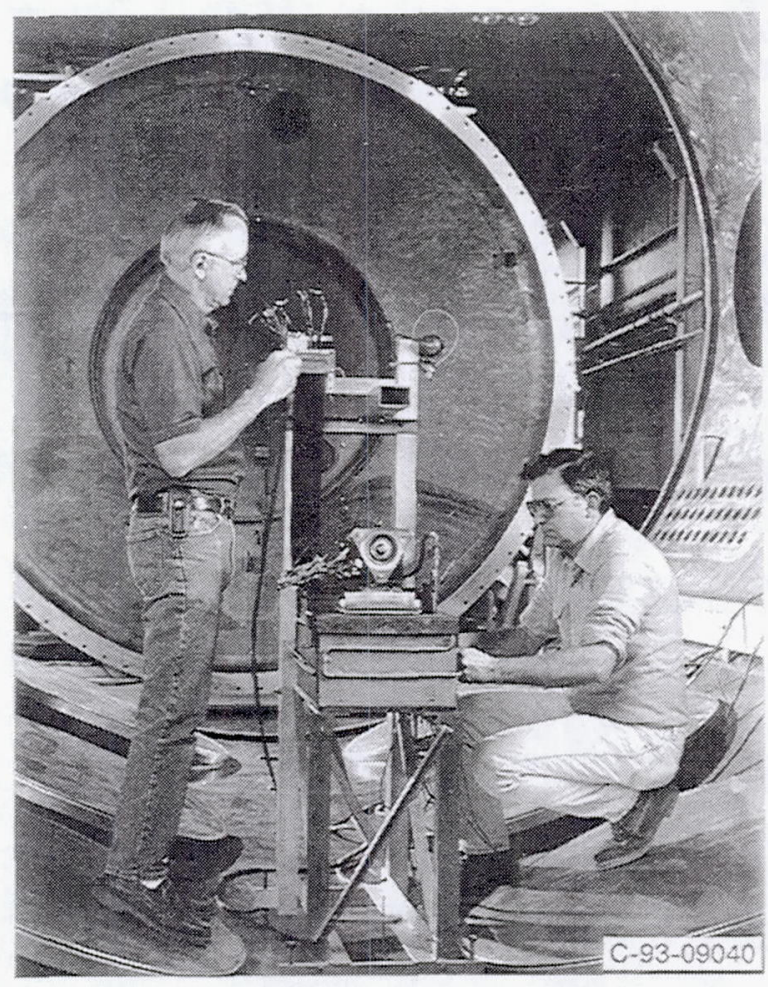

Figure 4.-TAL mounted on thrust stand in center of vacuum facility.

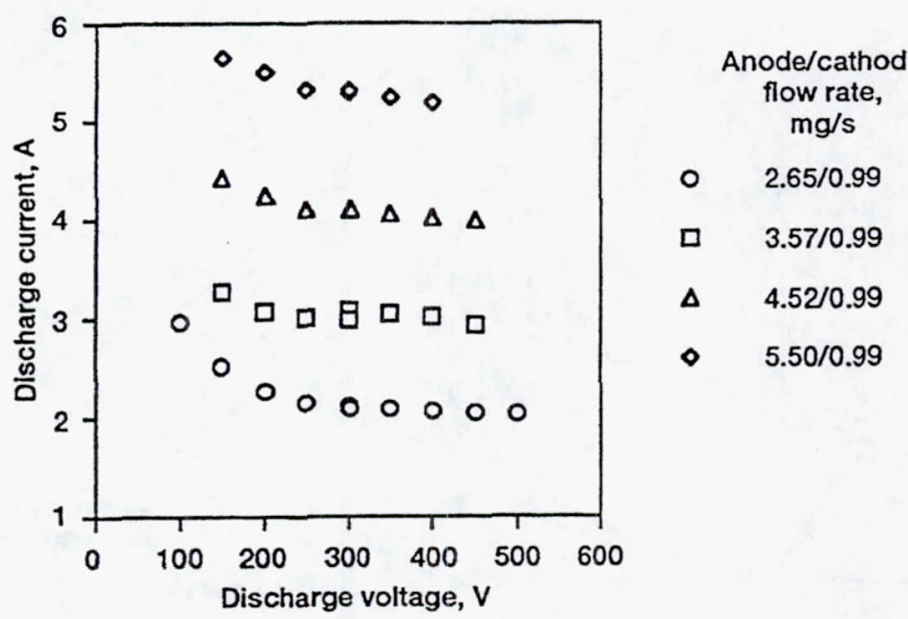

Figure 5.-Current-voltage characteristics at various flow rates. 


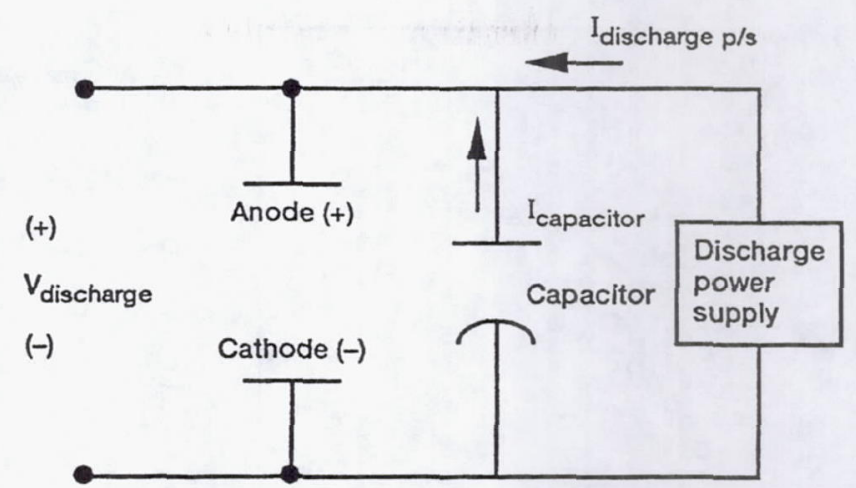

(a) Schematic of parameters measured with oscilloscope.

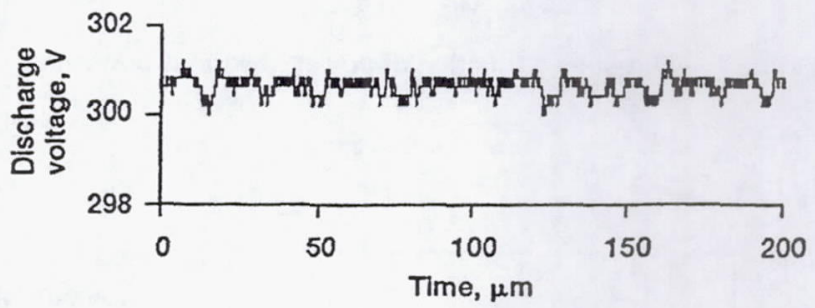

(b) Discharge voltage.

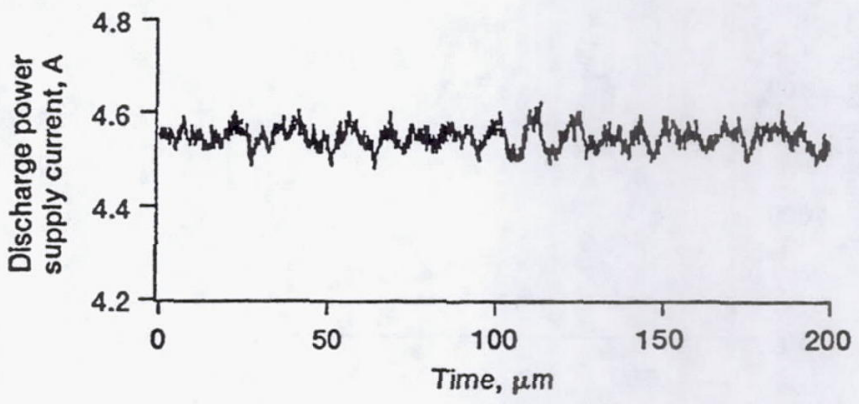

(c) Discharge power supply current.

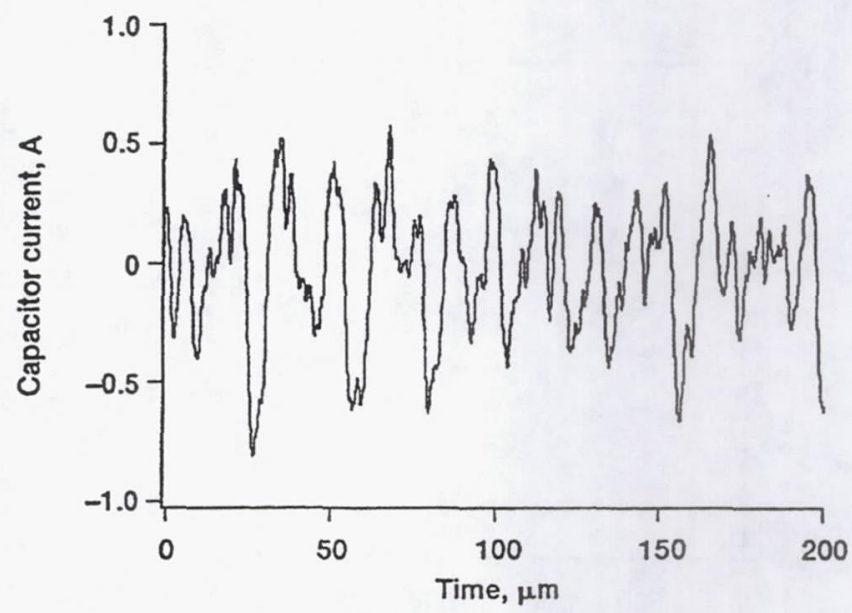

(d) Capacitor current.

Figure 6.-Oscilloscope traces of current and voltage at $4.5 \mathrm{~A}$ and $300 \mathrm{~V}$ thruster operating condition. 


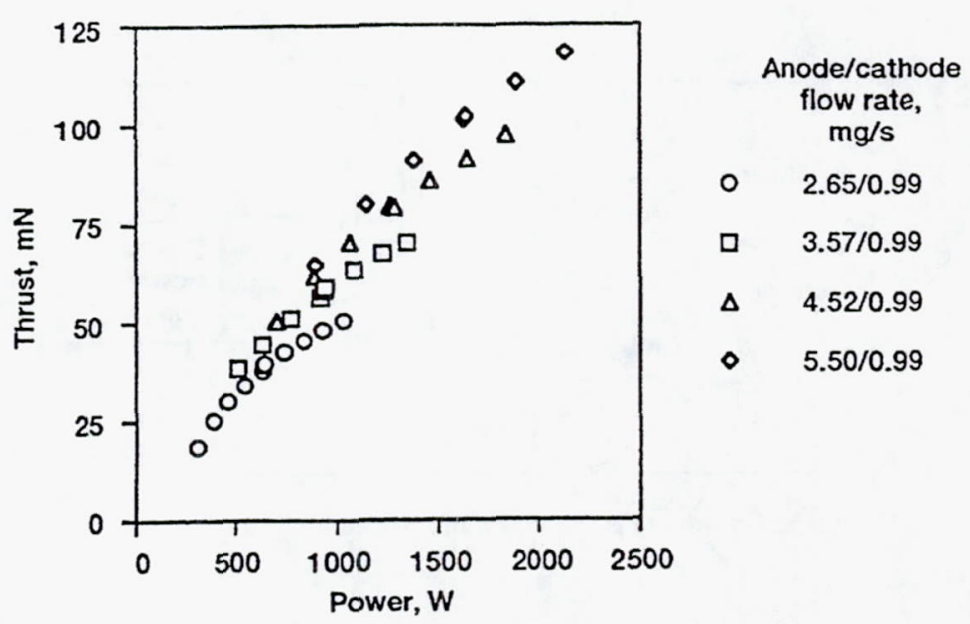

Figure 7.-Thrust as a function of power at various flow rates.

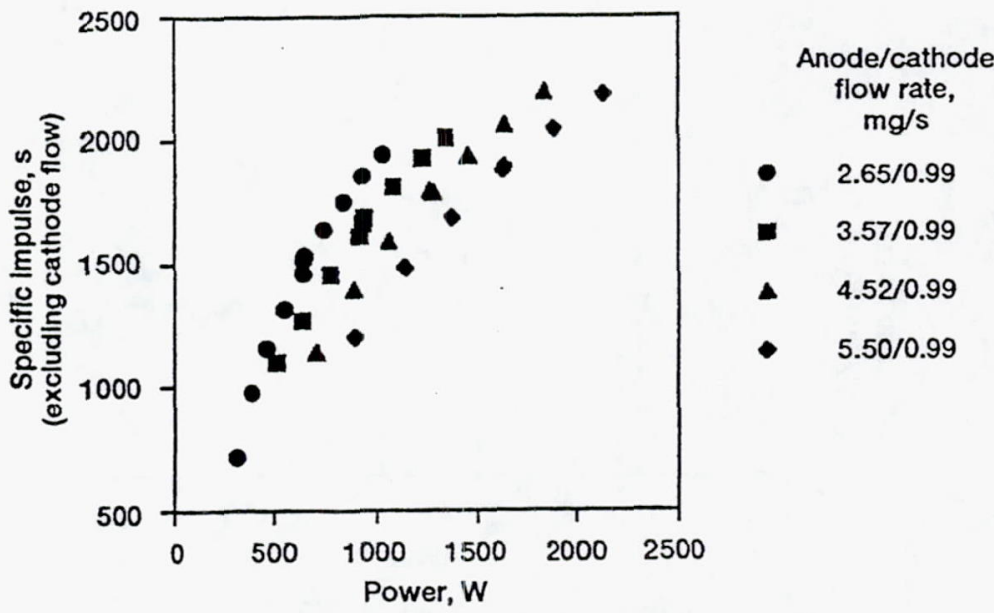

(a) Specific impulse versus power.

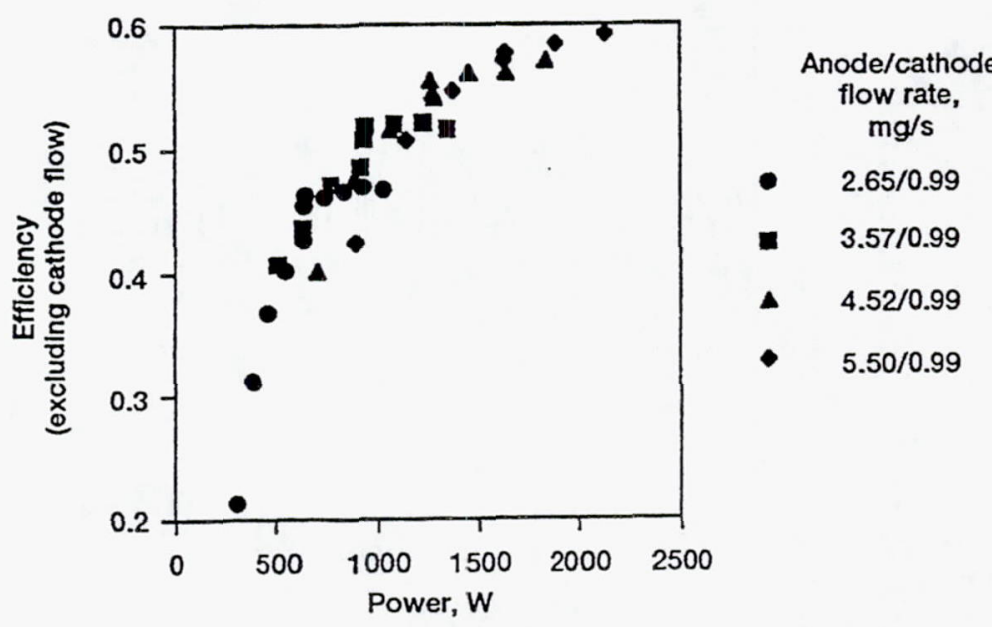

(b) Efficiency versus power.

Flgure 8.-Performance as a function of power at various flow rates. Mass flow through cathode not included in calculations. 


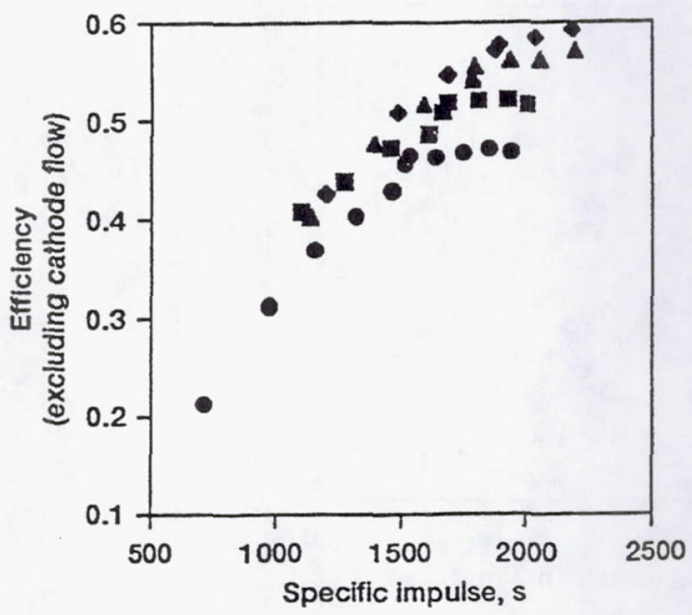

Anode/cathode

flow rate, $\mathrm{mg} / \mathrm{s}$

- $\quad 2.65 / 0.99$

- $3.57 / 0.99$

- $\quad 4.52 / 0.99$

- $\quad 5.50 / 0.99$

(a) Mass flow through cathode excluded in calculations.

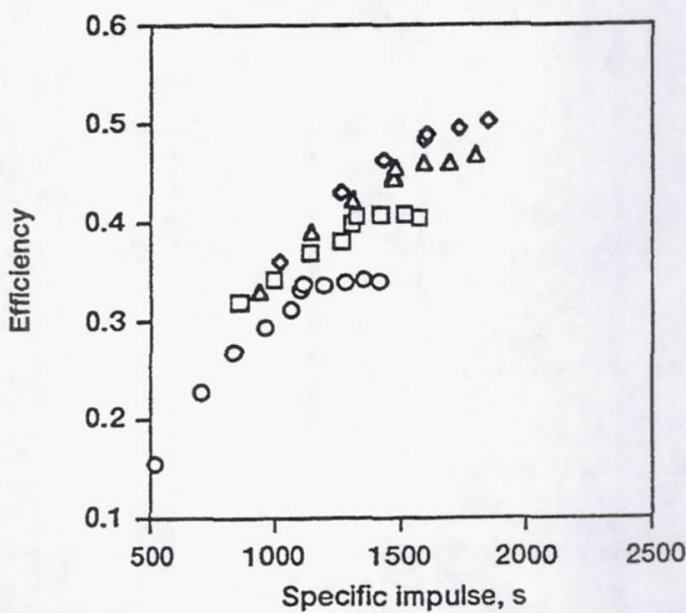

\section{Anode/cathode} flow rate, $\mathrm{mg} / \mathrm{s}$

- $2.65 / 0.99$

$\quad 3.57 / 0.99$

$\triangle \quad 4.52 / 0.99$

○ $\quad 5.50 / 0.99$

(b) Total mass flow used in calculations.

Figure 9.-Efficiency versus specific impulse at various flow rates. 


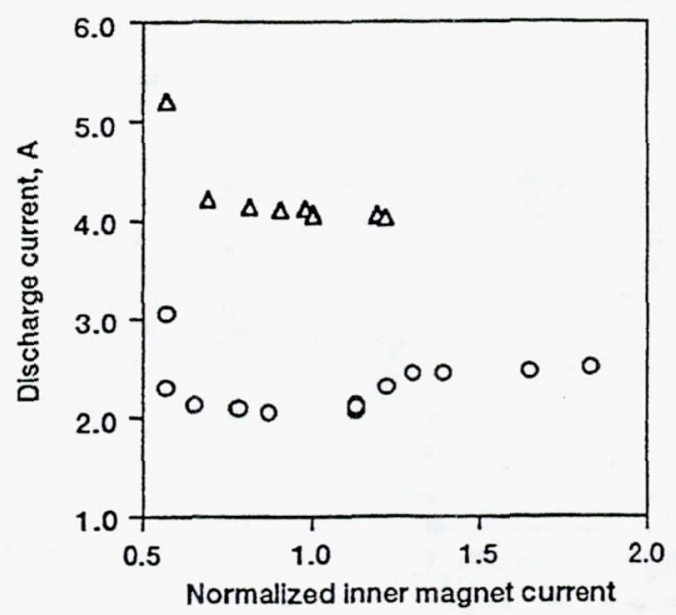

Anode/cathode flow rate,

$\mathrm{mg} / \mathrm{s}$

$\triangle \quad 4.52 / 0.99$

- $2.65 / 0.99$

(a) Effect on discharge current.

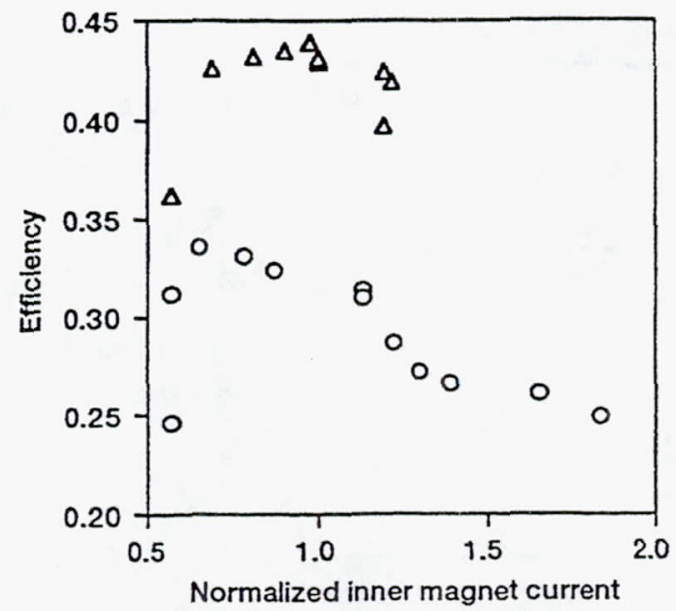

$$
\begin{array}{cc}
\begin{array}{c}
\text { Anode/cathode } \\
\text { flow rate, } \\
\text { mg/s }
\end{array} \\
\Delta \quad 4.52 / 0.99 \\
\Delta \quad 2.65 / 0.99
\end{array}
$$

(b) Effect on efficiency.

Figure 10.-Discharge current as a function of magnetic field strength at a constant discharge voltage of $300 \mathrm{~V}$ and various propellant flow rates. 


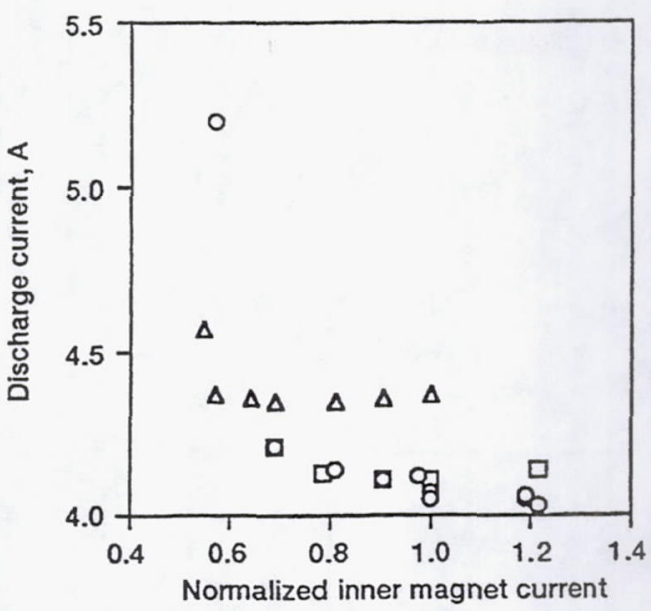
Discharge voltage
- $300 \mathrm{~V}$
口 $250 \mathrm{~V}$
$\triangle 150 \mathrm{~V}$

(a) Effect on discharge current.

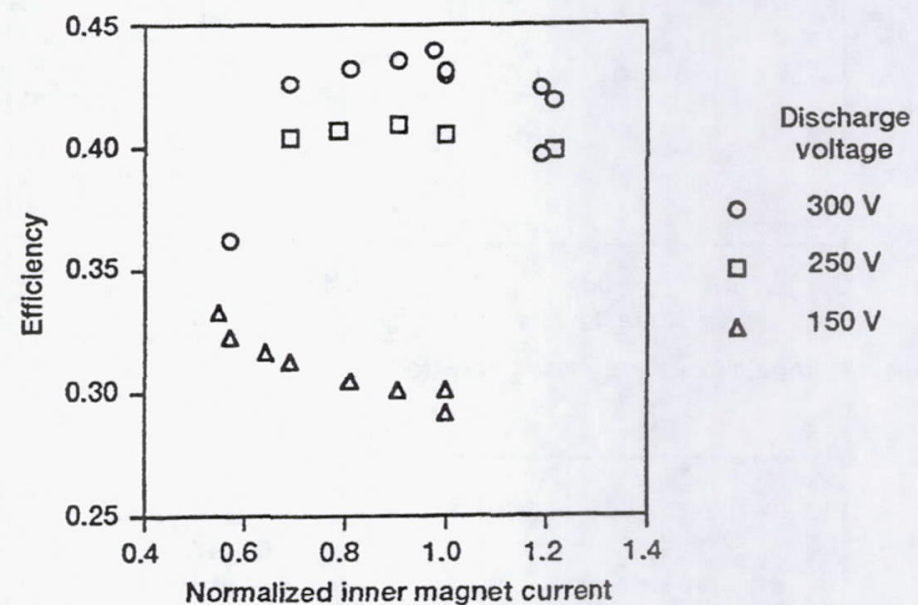

(b) Effect on efficiency.

Figure 11.-Effects of changing the magnetic field strength on thruster operation at a constant propellant flow rate of $5.5 \mathrm{mg} / \mathrm{s}$ and various discharge voltages.

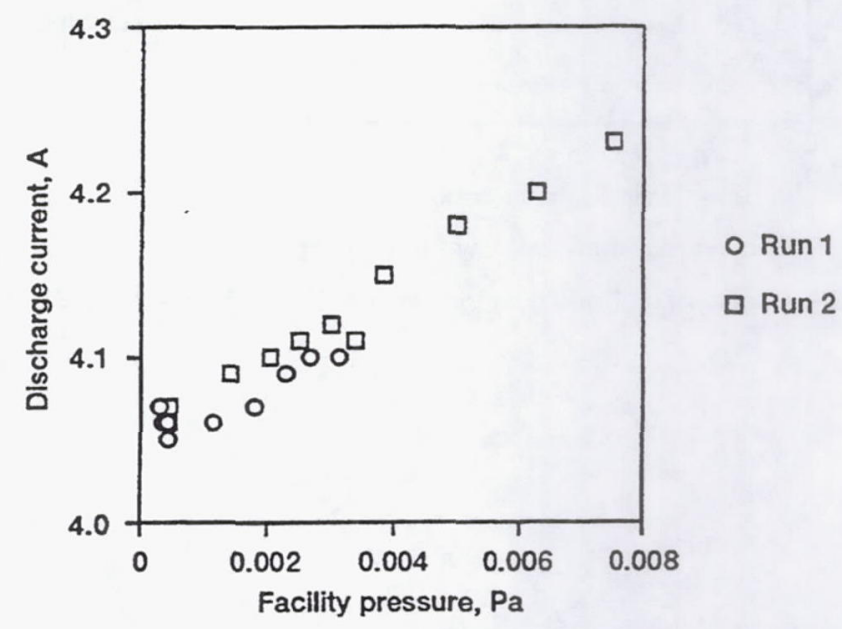

Figure 12.-Effects of facility pressure on discharge current. TAL operating at discharge voltage of $300 \mathrm{~V}$, anode flow rate of 4.52 $\mathrm{mg} / \mathrm{s}$, and cathode flow rate of $0.99 \mathrm{mg} / \mathrm{s}$. Pressures are corrected for xenon. 


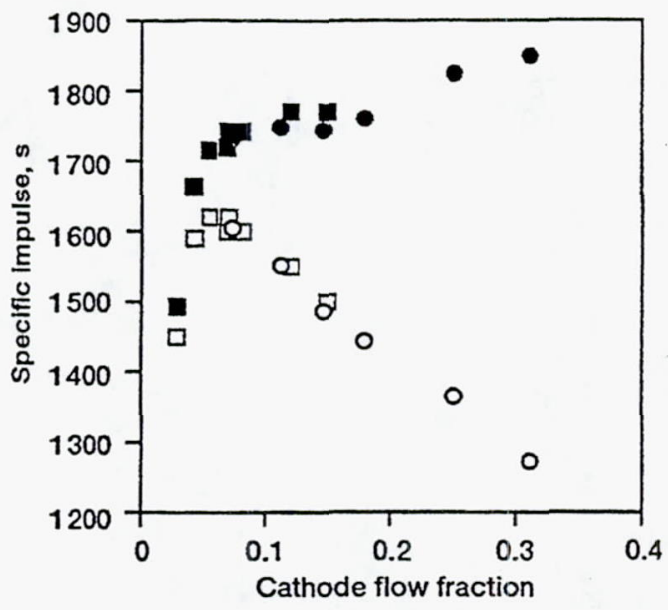

- TAL D-55, 4.1 A total flow

- TAL D-55, 4.1 A excluding cathode flow

口 SPT-100, 4.5 A [ref. 2] total flow

E SPT-100, 4.5 A [ref. 2] excluding cathode flow

(a) Specific impulse versus cathode flow fraction.

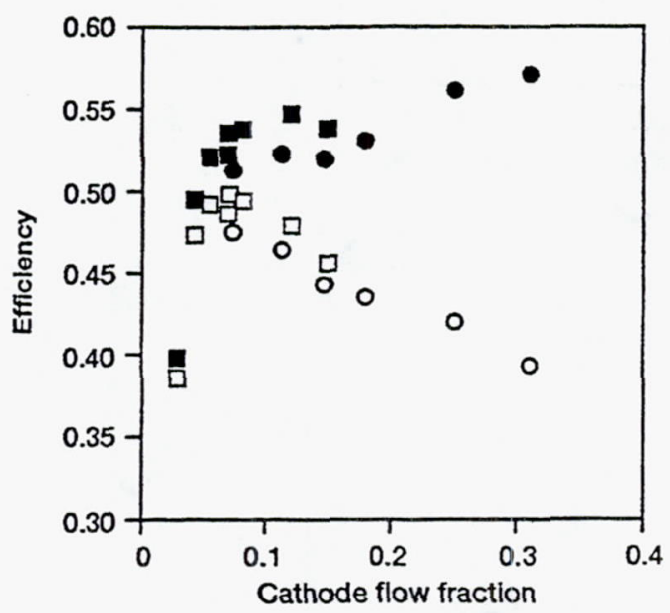

- TAL D-55, 4.1 A total flow

- TAL D-55, 4.1 A excluding cathode flow

口 SPT-100, 4.5 A [ref. 2] total flow

- SPT-100, 4.5 A [ref. 2] excluding cathode flow

(b) Efficiency versus cathode flow fraction.

Figure 13.-Effects of cathode flow fraction on SPT-100 and TAL D-55 performance. 


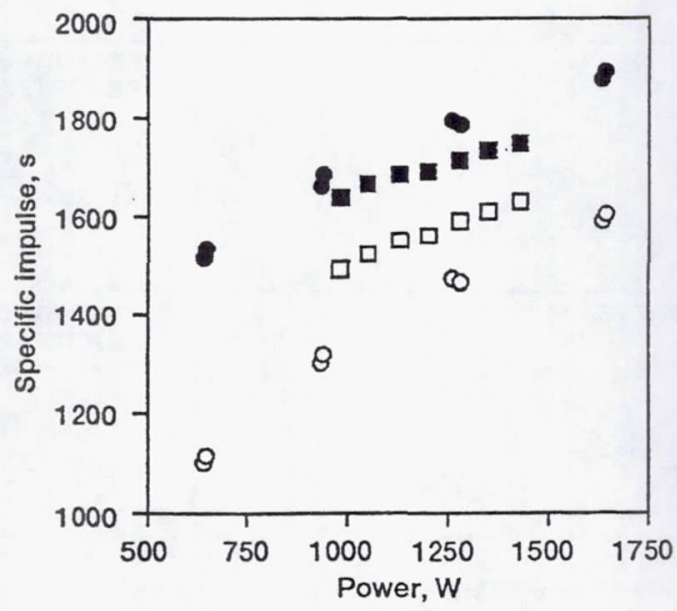

ㄴ SPT-100 [ref. 2] total flow

- SPT-100 [ref. 2] excluding cathode flow

- TAL D-55 total flow

- TAL D-55 excluding cathode flow

(a) Specific impulse versus power.

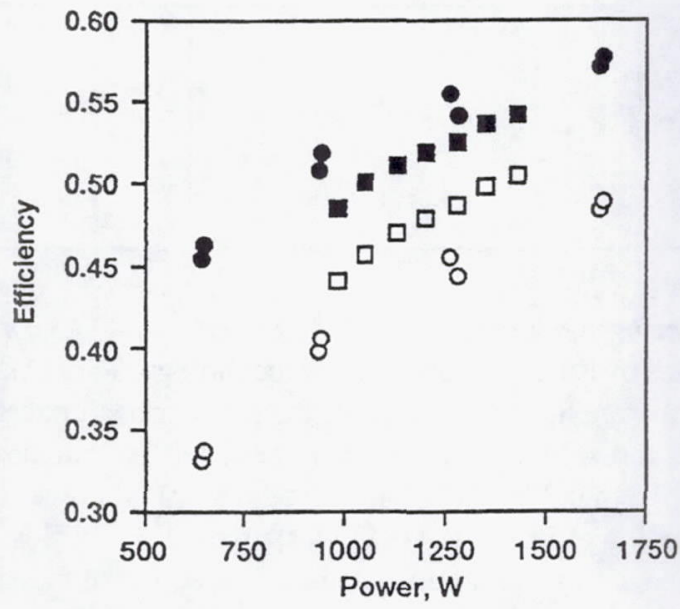

( SPT-100 [ref. 2] total flow

- SPT-100 [ref. 2] excluding cathode flow

- TAL D-55 total flow

- TAL D-55 excluding cathode flow

(b) Efficiency versus power.

Figure 14.-Comparisons of SPT-100 and TAL D-55 performance. 


\begin{tabular}{|c|c|c|c|}
\hline \multicolumn{3}{|c|}{ REPORT DOCUMENTATION PAGE } & $\begin{array}{l}\text { Form Approved } \\
\text { OMB No. 0704-0188 }\end{array}$ \\
\hline \multicolumn{4}{|c|}{$\begin{array}{l}\text { Public reporting burden for this collection of information is estimated to average } 1 \text { hour per response, including the time for reviewing instructions, searching existing data sources, } \\
\text { gathering and maintaining the data needed, and completing and reviewing the collection of information. Send comments regarding this burden estimate or any other aspect of this } \\
\text { collection of information, including suggestions for reducing this burden, to Washington Headquarters Services, Directorate for Intormation Operations and Reports, } 1215 \text { Jefferson } \\
\text { Davis Highway, Suite 1204, Arlington, VA 22202-4302, and to the Office of Management and Budget, Paperwork Reduction Project (0704-0188), Washington, DC 20503. }\end{array}$} \\
\hline 1. AGENCY USE ONLY (Leave blank) & \begin{tabular}{r|r} 
2. REPORT DATE \\
June 1994 \\
\end{tabular} & \multicolumn{2}{|c|}{$\begin{array}{l}\text { 3. REPORT TYPE AND DATES COVERED } \\
\text { Technical Memorandum }\end{array}$} \\
\hline \multicolumn{3}{|c|}{$\begin{array}{l}\text { 4. TITLE AND SUBTITLE } \\
\text { Operating Characteristics of the Russian D-55 Thruster with Anode Layer }\end{array}$} & \multirow{2}{*}{$\begin{array}{l}\text { 5. FUNDING NUMBERS } \\
\text { WU-506-42-31 }\end{array}$} \\
\hline \multicolumn{3}{|c|}{$\begin{array}{l}\text { 6. AUTHOR(S) } \\
\text { John M. Sankovic, Thomas W. Haag, and David H. Manzella }\end{array}$} & \\
\hline \multicolumn{3}{|c|}{$\begin{array}{l}\text { 7. PERFORMING ORGANIZATION NAME(S) AND ADDRESS(ES) } \\
\text { National Aeronautics and Space Administration } \\
\text { Lewis Research Center } \\
\text { Cleveland, Ohio } 44135-3191\end{array}$} & $\begin{array}{l}\text { ORMING ORGANIZATION } \\
\text { RT NUMBER }\end{array}$ \\
\hline \multicolumn{3}{|c|}{ 9. SPONSORING/MONITORING AGENCY NAME(S) AND ADDRESS(ES) } & $\begin{array}{l}\text { NSORING/MONITORING } \\
\text { NCY REPORT NUMBER } \\
\text { A TM-106610 } \\
\text { A-94-3011 }\end{array}$ \\
\hline \multicolumn{4}{|c|}{$\begin{array}{l}\text { 11. SUPPLEMENTARY NOTES } \\
\text { Prepared for the 30th Joint Propulsion Conference cosponsored by AIAA, ASME, SAE, and ASEE, Indianapolis, Indiana, June 27-30, 1994. John M. } \\
\text { Sankovic and Thomas W. Haag, NASA Lewis Research Center, and David H. Manzella, NYMA, Inc., Engineering Services Division, 2001 Aerospace } \\
\text { Parkway, Brook Park, Ohio } 44142 \text { (work funded by NASA Contract NAS3-27186). Responsible person, John M. Sankovic, organization code 5330, } \\
\text { (216) } 977-7429 \text {. }\end{array}$} \\
\hline \multicolumn{3}{|c|}{$\begin{array}{l}\text { 12a. DISTRIBUTION/AVAILABILITY STATEMENT } \\
\text { Unclassified - Unlimited } \\
\text { Subject Category } 20\end{array}$} & 12b. DISTRIBUTION CODE \\
\hline \multicolumn{4}{|c|}{$\begin{array}{l}\text { 13. ABSTRACT (Maximum } 200 \text { words) } \\
\text { Performance measurements of a Russian engineering-model Thruster with Anode Layer (TAL) were obtained as part of } \\
\text { a program to evaluate the operating characteristics of Russian Hall-thruster technology. The TAL model D-55 was } \\
\text { designed to operate in the } 1-2 \mathrm{~kW} \text { power range on xenon. When received, the thruster had undergone only a few hours } \\
\text { of acceptance testing by the manufacturer. Direct thrust measurements were obtained at a background pressure of } \\
0.0003 \mathrm{~Pa}\left(2 \times 10^{-6} \text { torr) at power levels ranging from } 0.3 \mathrm{~kW} \text { to } 2.1 \mathrm{~kW} \text {. At the nominal power level of } 1.3 \mathrm{~kW} \text {, a }\right. \\
\text { specific impulse level of } 1600 \mathrm{~s} \text { with a corresponding efficiency of } 0.48 \text { was attained. At all flow rates tested, the } \\
\text { efficiency increased linearly with specific impulse until a maximum was reached, and then the efficiency leveled off. } \\
\text { Increasing the anode flow rate shifted the efficiency upward, reaching } 0.50 \text { at } 1850 \mathrm{~s} \text { specific impulse. The thruster was } \\
\text { equipped with inner and outer electromagnets which were isolated from the discharge and from each other. Variation of } \\
\text { the magnetic field, obtained by changing the currents through the magnets, had little effect on performance, except at } \\
\text { current levels below } 70 \% \text { of nominal. For a given operating condition, the performance was slightly affected by facility } \\
\text { pressure. As the pressure was increased by a factor of thirty to } 0.008 \mathrm{~Pa} \text { ( } 6 \mathrm{x} 10^{-5} \text { torr), the current steadily increased by } \\
4 \% \text {, and the thrust increased by } 2 \% \text {. Performance comparisons were made with the Stationary Plasma Thruster, and the } \\
\text { efficiency and specific impulse values were similar at power levels ranging from } 0.9 \mathrm{~kW} \text { to } 1.5 \mathrm{~kW} \text {. Endurance testing } \\
\text { was not performed, and comparisons of lifetime were not made. }\end{array}$} \\
\hline \multirow{2}{*}{\multicolumn{3}{|c|}{$\begin{array}{l}\text { 14. SUBJECT TERMS } \\
\text { Electric propulsion; Thruster with anode layer; Russian technology }\end{array}$}} & $\begin{array}{c}\text { 15. NUMBER OF PAGES } \\
23 \\
\end{array}$ \\
\hline & & & $\begin{array}{r}\text { 16. PRICE CODE } \\
\mathrm{AO} 3 \\
\end{array}$ \\
\hline $\begin{array}{l}\text { 17. SECURITY CLASSIFICATION } \\
\text { OF REPORT } \\
\text { Unclassified }\end{array}$ & $\begin{array}{l}\text { 18. SECURITY CLASSIFICATION } \\
\text { OF THIS PAGE } \\
\text { Unclassified }\end{array}$ & $\begin{array}{l}\text { 19. SECURITY CLASSIFICATION } \\
\text { OF ABSTRACT } \\
\text { Unclassified }\end{array}$ & 20. LIMITATION OF ABSTRACT \\
\hline NSN 7540-01-280-5500 & & & $\begin{array}{l}\text { andard Form } 298 \text { (Rev. } 2-89) \\
\text { escribed by ANSI Std. Z39-18 } \\
8-102\end{array}$ \\
\hline
\end{tabular}

